\title{
Data Recovery Excavations at 41BX1412 A Multicomponent Site in McAllister Park, San Antonio, Bexar County, Texas
}

Steve A. Tomka

Raba Kistner

Follow this and additional works at: https://scholarworks.sfasu.edu/ita

Part of the American Material Culture Commons, Archaeological Anthropology Commons, Environmental Studies Commons, Other American Studies Commons, Other Arts and Humanities Commons, Other History of Art, Architecture, and Archaeology Commons, and the United States History Commons

Tell us how this article helped you.

This Article is brought to you for free and open access by the Center for Regional Heritage Research at SFA ScholarWorks. It has been accepted for inclusion in Index of Texas Archaeology: Open Access Gray Literature from the Lone Star State by an authorized editor of SFA ScholarWorks. For more information, please contact cdsscholarworks@sfasu.edu. 


\section{Data Recovery Excavations at 41BX1412 A Multicomponent Site in McAllister Park, San Antonio, Bexar County, Texas \\ Creative Commons License \\ (c) (1) (8)}

This work is licensed under a Creative Commons Attribution-NonCommercial 4.0 International License 


\section{Data Recovery Excavations at 41BX1412 A Multicomponent Site in $\mathbf{M}^{\mathrm{c}}$ Allister Park, San Antonio, Bexar County, Texas}
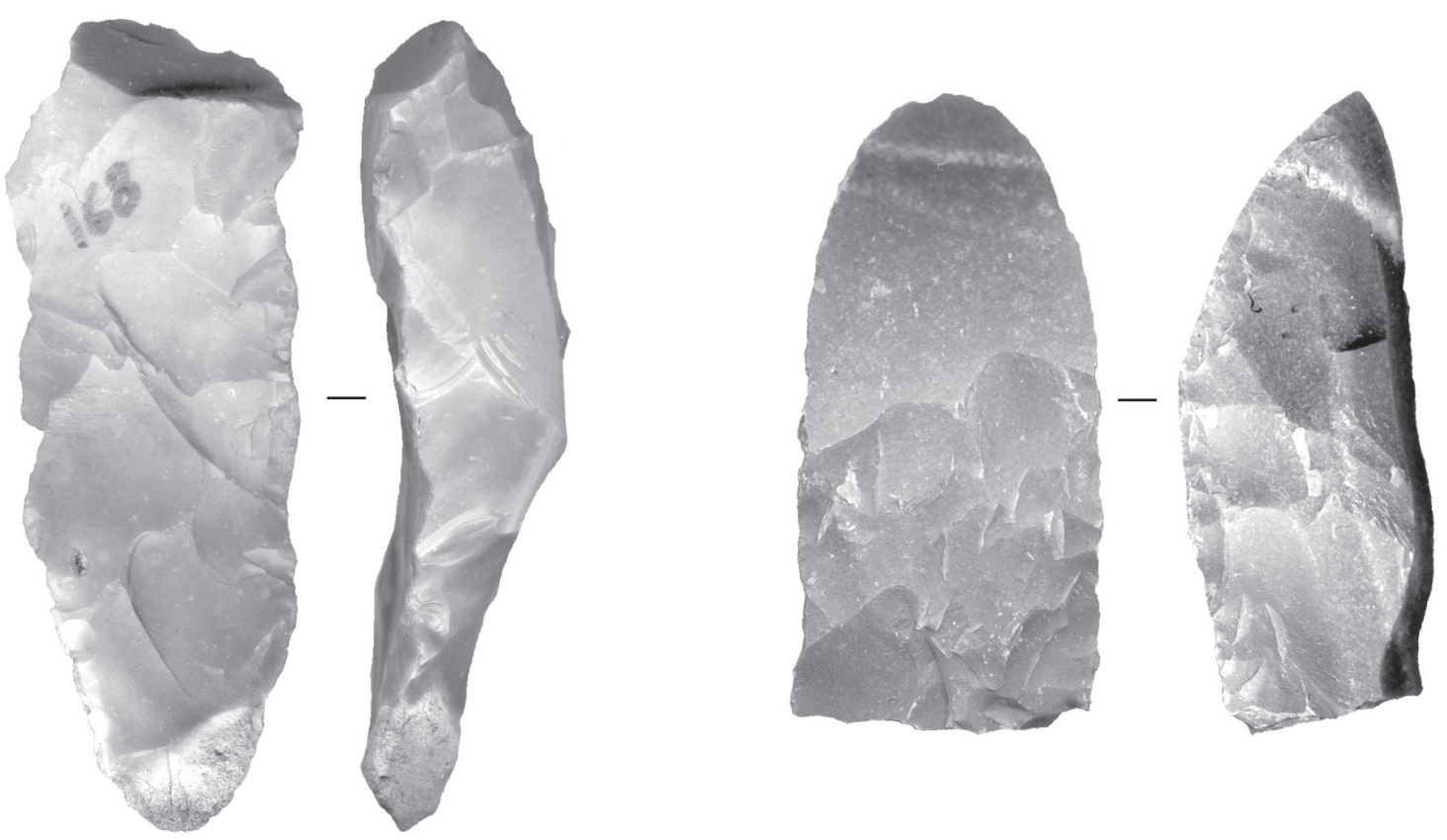

by

Steve A. Tomka

with contributions by

Cory J. Broehm, Anne A. Fox, Jeffrey R. Francis,

Raymond P. Mauldin, Rick C. Robinson,

Marybeth S. F. Tomka, and Jason D. Weston

Center for Archaeological Research

The University of Texas at San Antonio Archaeological Survey Report, No. 324
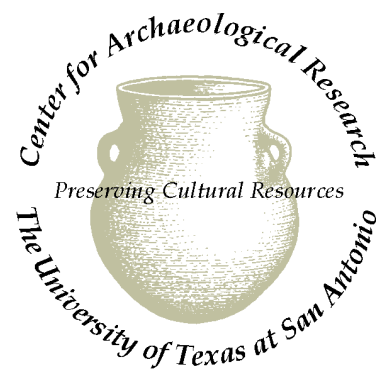


\title{
Data Recovery Excavations at 41BX1412 A Multicomponent Site in $\mathrm{M}^{\mathrm{c}}$ Allister Park, San Antonio, Bexar County, Texas
}

\author{
by \\ Steve A. Tomka \\ with contributions by \\ Cory J. Broehm, Anne A. Fox, Jeffrey R. Francis, Raymond P. Mauldin, \\ Rick C. Robinson, Marybeth S. F. Tomka, and Jason D. Weston
}

Steve A. Tomka

Principal Investigator

Texas Antiquities Permit No. 2466

Ccopyright 2002

Center for Archaeological Research

The University of Texas at San Antonio

Archaeological Survey Report, No. 324 
The following information is provided in accordance with the General Rules of Practice and Procedure, Chapter 41.11 (Investigative Reports), Texas Antiquities Committee:

1. Type of investigation: Mitigation

2. Project name: McAllister Park Data Recovery (41BX1412)

3. County: Bexar

4. Principal investigator: Steve A. Tomka

5. Name and location of sponsoring agency: San Antonio Parks and Recreation Department, 506 Dolorosa, P.O. Box 839966, San Antonio, Texas, 78283-3966

6. Texas Antiquities Permit No.: 2466

7. Published by the Center for Archaeological Research, The University of Texas at San Antonio, 6900 N. Loop 1604 W., San Antonio, Texas 78249-0658, 2002

A list of publications offered by the Center for Archaeological Research is available. Call (210) 458-4378; write to the Center for Archaeological Research, The University of Texas at San Antonio, 6900 N. Loop 1604 W., San Antonio, Texas 78249-0658; e-mail to car@lonestar.utsa.edu; or visit CAR’s web site at http://car.utsa.edu. 


\begin{abstract}
The Center for Archaeological Research (CAR) of The University of Texas at San Antonio contracted with the city of San Antonio Parks and Recreation Department to conduct data recovery excavations at site 41BX1412 in McAllister Park, northeast San Antonio, Bexar County, Texas. Data recovery excavations were initiated at the site in order to mitigate the impact of the construction-related disturbances that would result from the proposed expansion of Bee Tree Drive towards Starcrest Drive at the southeastern edge of the park. The expansion of Bee Tree Drive could not be redesigned to avert impact to 41BX1412, a multicomponent archaeological site recorded during a survey conducted in 2000 by CAR personnel. The data recovery efforts consisted of the investigation of a total of $128.5 \mathrm{~m}^{2}$ of the site. The fieldwork was carried out between September 22 and 29, 2000, under Texas Antiquities Permit Number 2466. Steve A. Tomka served as project archaeologist.

Testing suggested the presence of an Early Archaic, and a possible late Paleoindian, component at the site. Data recovery excavations revealed no intact features. More importantly, the excavations indicated that although an Early Archaic cultural zone may exist at the site, buried some $60 \mathrm{~cm}$ below surface, no in situ temporal diagnostics were recovered from this zone. Unexpectedly, the data recovery efforts yielded Middle Archaic temporal diagnostics but no intact deposits. A number of lines of evidence suggest that the site has undergone significant disturbance, most likely during the original construction of Bee Tree Drive. The results of the fieldwork and analysis suggest that the site has been heavily disturbed and does not warrant listing to the National Register of Historic Places nor designation as a State Archeological Landmark.
\end{abstract}




\section{Contents}

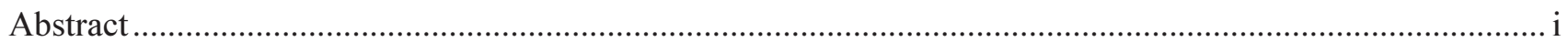

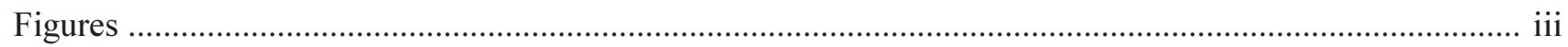

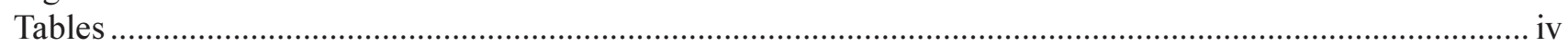

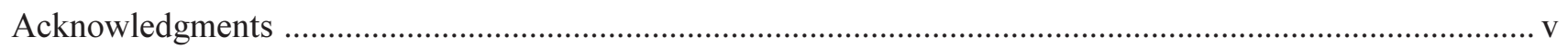

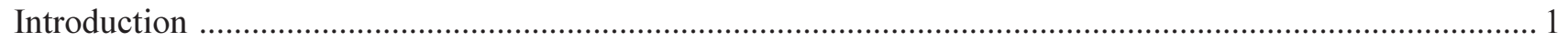

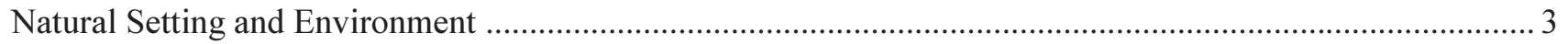

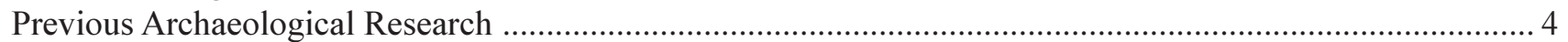

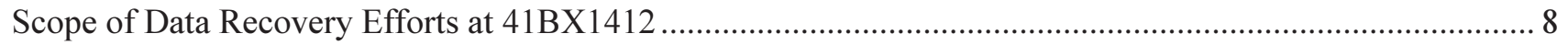

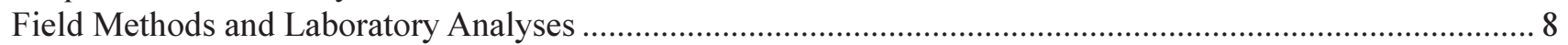

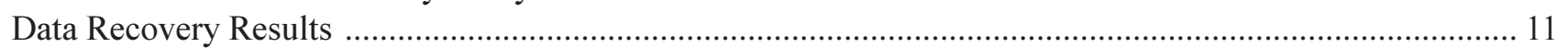

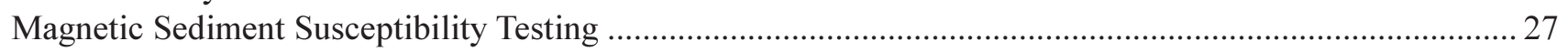

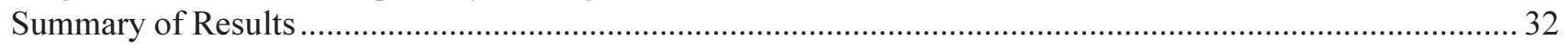

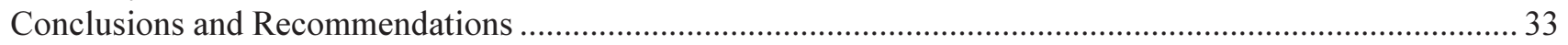

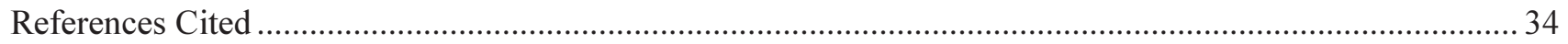

Appendix A

Texas Historical Commission Concurrence Letter ................................................................................. 40

Appendix B

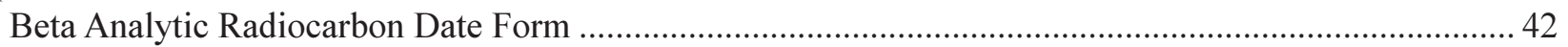

Appendix C

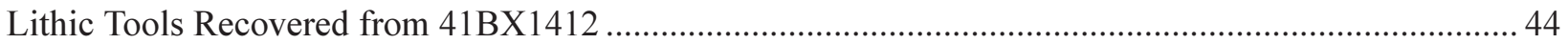




\section{Figures}

Figure 1. Location of McAllister Park within Bexar County, Texas. ......................................................... 1

Figure 2. Location of site 41BX1412 within McAllister Park. .................................................................... 2

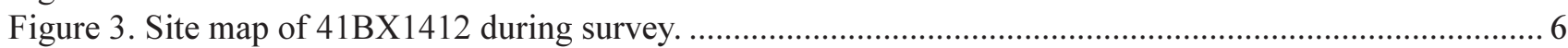

Figure 4. Volunteer from the Southern Texas Archaeological Association. ............................................... 9

Figure 5. Middle school students from Omar Bradley Middle School visiting the site................................. 9

Figure 6. Site map of 41BX1412 showing shovel tests, hand-excavated blocks, and bladed areas. ............... 10

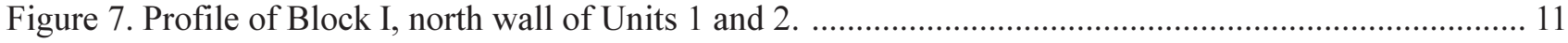

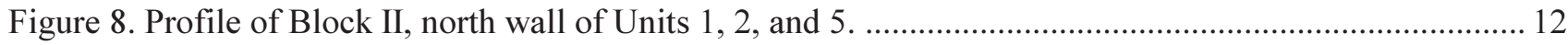

Figure 9. Temporal diagnostic artifacts recovered from 41BX1412 during mitigation. ................................. 17

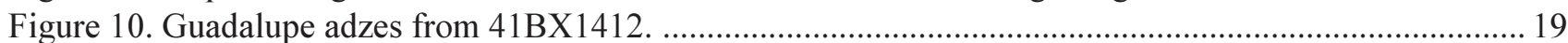

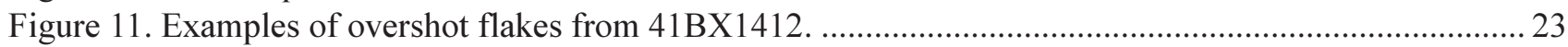

Figure 12. Distribution of adjusted unmodified debitage counts by $1 \mathrm{~m}^{3}$ level and block. .......................... 24

Figure 13. Plot of mean maximum dimensions by level and block of debitage. ..........................................2 24

Figure 14. Distribution by level and block of the percentage of patinated debitage .................................... 25

Figure 15. Distribution of adjusted burned rock counts by $1 \mathrm{~m}^{3}$ level, both blocks combined...................... 27

Figure 16. Mass specific sediment susceptibility values for samples from Block I.......................................3 31

Figure 17. Mass specific sediment susceptibility values for samples from Block II. .................................. 31 


\section{Tables}

Table 1. Artifacts recovered from 41BX1412 during 1999 survey/testing .................................................. 7

Table 2. Distribution by excavation unit of artifact categories recovered from 41BX1412 ......................... 13

Table 3. Distribution by vertical provenience of artifact categories recovered from 41BX1412 ................... 13

Table 4. Distribution of lithic artifact categories by STs, EU, and block excavation units ........................... 15

Table 5. Distribution of lithic artifact categories from STs, EUs, and block excavation units by level ........... 16

Table 6. Magnetic sediment susceptibility for a variety of substances ........................................................2 29

Table 7. Presence/absence of cultural material and mass specific sediment susceptibility scores for

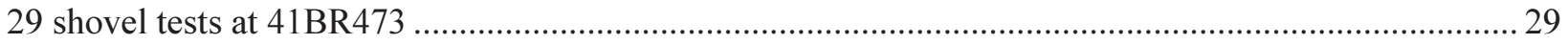

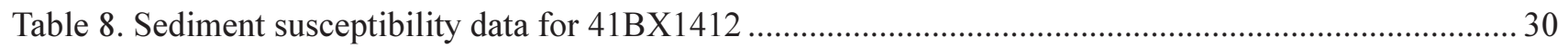

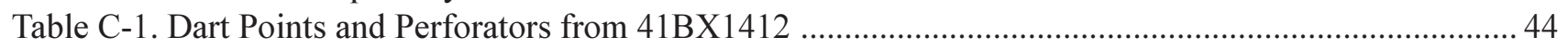

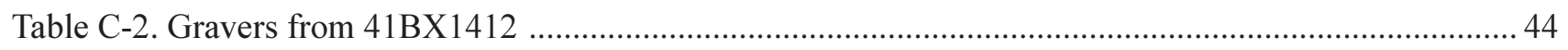

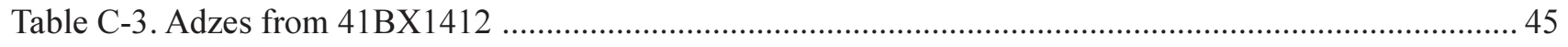

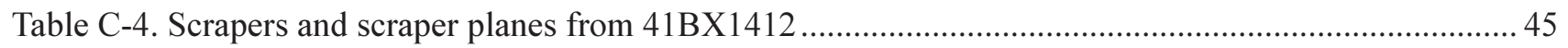

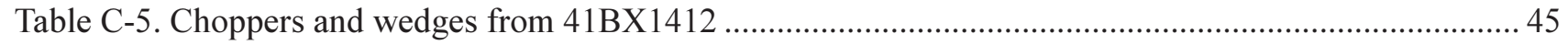

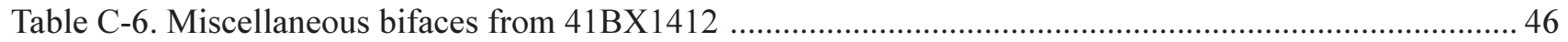

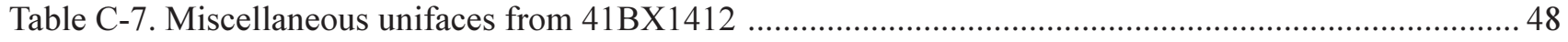

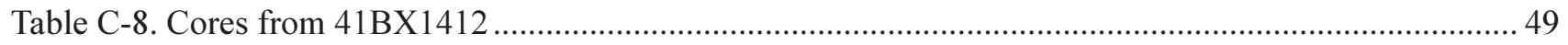




\section{Acknowledgments}

The successful completion of this project is owed in a large part to the able and hard working field crew and lab technicians that helped in the excavation and laboratory processing of the materials obtained during the project. They include the following individuals: Amy Duckworth, Jeff Francis, Connie Gibson, Carol Leezer, Shanti Morell-Hart, Scott Speal, and Kristi Ulrich. In addition, a great deal of thanks are due to the Southern Texas Archaeological Association volunteers that participated in the fieldwork. The hard working gang consisted of Roy Banning, Jackie Boyd, Carol Jameson, Harry Johnson, Lyn Kraft, Mary B. Packard, Lee LeTourneau, and Jan Watts. Mr. Steve Uncapher, of the Parks and Recreation Department of the city of San Antonio, facilitated the project in many ways and has been a pleasure to work with. The assistant director of the Center for Archaeological Research (CAR), Dr. Raymond P. Mauldin, was extremely helpful in the field and supervised the soil susceptibility study. Jason Weston and Cory Broehm carried out the laboratory work dealing with the soil susceptibility analysis and Rick Robinson carried out the lithic debitage analysis. I also gratefully acknowl-

edge the support of additional CAR staff, in particular, Maryanne King and Johanna Hunziker, the technical editors that saw this report through production. Bruce Moses and Rick Young mapped the site, drafted the site map, and created the illustrations present in this report. Their help is also greatly appreciated. A special thanks is also extended to Dr. Robert J. Hard, former CAR director, for his support of this project. 



\section{Introduction}

Between September 22 and 29, 2000, under contract with the city of San Antonio Parks and Recreation Department, and under Texas Antiquities Permit Number 2466, the Center for Archaeological Research (CAR) of The University of Texas at San Antonio conducted data recovery excavations at 41BX1412, located on a upland terrace of Mud Creek, in the central portion of McAllister Park (Figures 1 and 2). The site is a multicomponent campsite with a thin veneer of early twentieth-century historic materials, and what initially were thought to be buried Early Archaic and probable Paleoindian components. Following initial testing of the site, CAR recommended that data recovery efforts be undertaken at 41BX1412 (Tomka and Robinson 2000). The Texas Historical Commission (THC) concurred with this recommendation. This report provides a summary of the data recovery efforts and analysis results of the materials recovered from 41BX1412.

Data recovery efforts consisted of a two-pronged approach: the hand excavation of two blocks measuring $2 \times 2$ meters and $2 \times 3$ meters; and the machine excavation of two intersecting trenches $(3 \times 27 \mathrm{~m}$ and $3 \times 12.5 \mathrm{~m})$. Excavations in the block units were intended to recover detailed information on features, stratigraphy, and representative samples of artifacts. The machine-excavated trenches were intended to expose large areas in search of buried features that would then be excavated by hand.

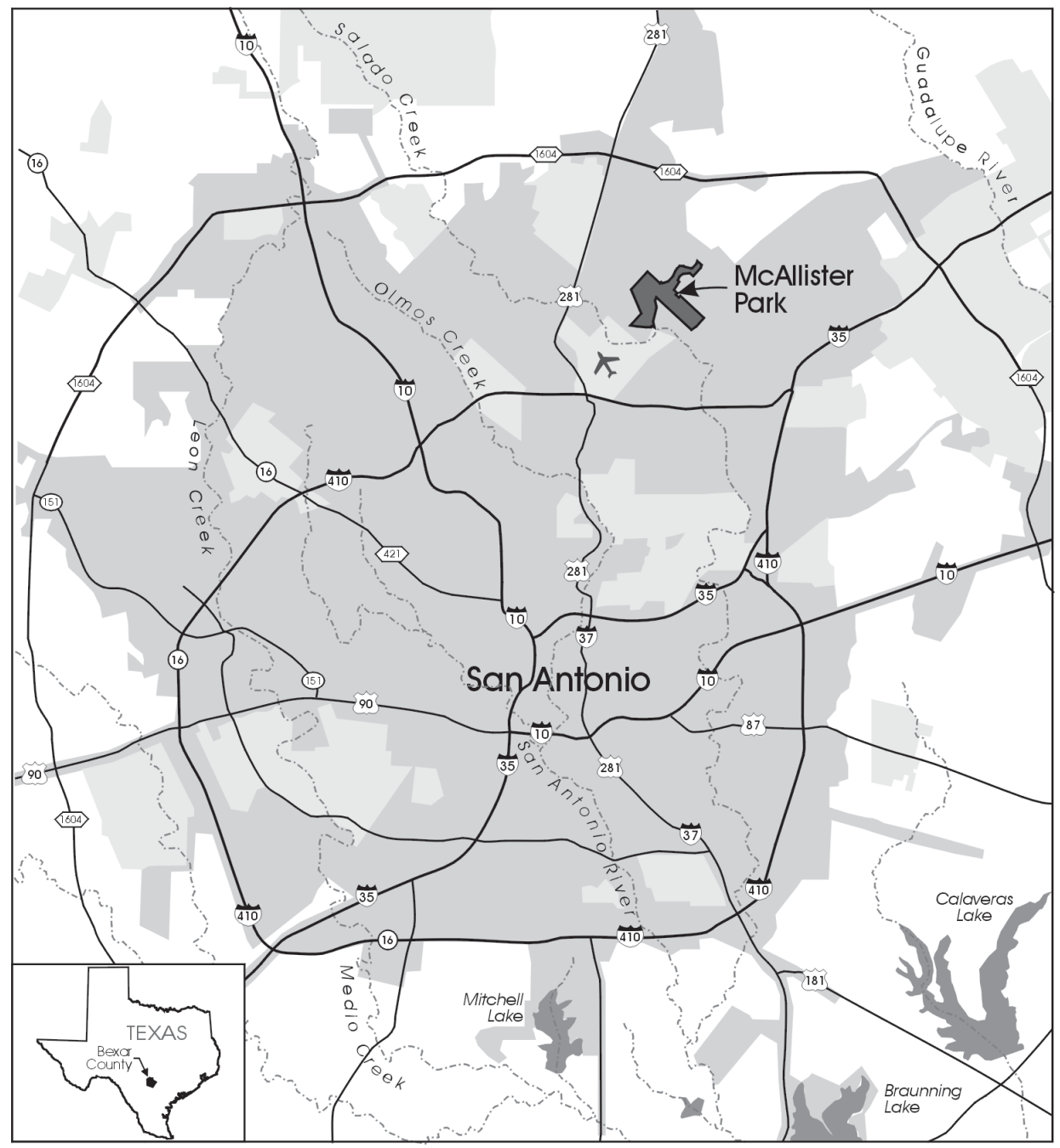

Figure 1. Location of McAllister Park within Bexar County, Texas. 
This page has been

redacted because it

contains restricted

information. 


\section{Natural Setting and Environment}

\author{
Jeffrey R. Francis
}

McAllister Park, situated in northeast Bexar County, lies within a transitional zone between two major physiographic regions: the Blackland Prairie to the south and the Edwards Plateau to the north. Within Bexar County converge three major physiographic regions of south-central Texas: the Edwards Plateau, the Blackland Prairie, and the Gulf Coast Plain (Black and McGraw 1985:42). These three regions can be further subdivided into a number of smaller areas, each with distinctive topographic and biotic associations (Black 1989:6). The convergence of these biotic zones creates a rich environment of game and edible plants (Blair 1950).

Rising abruptly in northern Bexar County, the Balcones Escarpment is a transitional zone between the Blackland Prairie and the Edwards Plateau. Formed from an uplifted fault zone during the Miocene Epoch ( $\sim 20$ million years ago), these deeply eroded limestone foothills extend in an arc from Waco, through northern Bexar County, then southwest to Del Rio. Topography of the Balcones Escarpment is marked by rugged terrain with low steep hills cut by numerous small intermittent streams. Soils are typically thin and rocky. Vegetation tends to be transitional between the semi-arid Tamaulipan and sub-humid Texan and Balconian biotic zones. The area is characterized by patchy outgrowths of juniper, cedar, and mesquite trees in the uplands. Elm, acacia, and cottonwood can be found along the lowland floodplains. Various nut trees, numerous varieties of cacti, dense thickets of agarita, and other edible plants can also be found. Commonly known as the Texas "hill country," this rough terrain gives rise to the Edwards Plateau, which is the major physiographic region of west-central Texas.

The Edwards Plateau includes much of west-central Texas encompassing several counties to the north and west of Bexar County. Although characterized as a plateau, the region is composed of porous limestone deeply cut by narrow stream courses resulting in a high relief, rugged topography (Black and McGraw 1985:42). Many of the perennial streams that flow through the Balcones Escarpment, the Blackland Prairie, and the Gulf Coast Plain have their headwaters in the limestone springs of the Edwards Plateau. As with the Balcones Escarpment, the soils in the Edwards Plateau tend to be thin and rocky, except for the alluvial lowlands in the stream valleys. The flora and fauna of the region is associated with the Balconian Biotic Province. The fauna is characterized by a variety of species from adjacent provinces, however, the flora is quite distinct (Black and McGraw 1985:43). Mexican cedar, Texas oak, and stunted live oak are prevalent in the upland areas, while mesic forests of live oak, elm, hackberry, and several varieties of deciduous nut trees, such as pecan, characterize the riverine environments. The climate of the Edwards Plateau region is considered semi-arid, with an average annual rainfall of 38 inches $(97 \mathrm{~cm}$ ) or less (Bomar 1995:56). Short-term (summer) droughts are common, and long-term droughts lasting a year or more occur at irregular intervals.

The Blackland Prairie is a relatively narrow band of black waxy clays that begin southwest of Bexar County and extend through northeast Texas, terminating at the Red River. Although not a true plain, the Blackland Prairie is an extension of the Gulf Coast Plain. Topographically, it is characterized by gently rolling hills with comparatively low relief. The soils of this region tend to be deep in alluvial valleys and thin in the uplands, depending on the hydrology of the local area. The flora and fauna of the Blackland Prairie is considerably diverse and includes a variety of species from adjacent provinces. Terrestrial species include whitetailed deer, jackrabbits, and coyotes. Riverine species include turtles, largemouth bass, and alligators. The southern aspect is associated with the Tamaulipan Biotic Province, while the northern zone is part of the Texan Biotic Province. The former is a semi-arid to sub-humid brushland dominated by recent intrusions of thorny brush such as mesquite and various acacias, while the latter is a mix of grassland and forest vegetation. Early historic records indicate that grassland and savanna communities dominated the Tamaulipan province before the introduction of farming and ranching industries. Just southeast of the Blackland Prairie is a dense oak and hickory forest, known as the Post Oak Belt (Black 1989:12). 
To the southeast, the Post Oak Belt is contiguous with the Gulf Coast Plain, which extends to the Gulf of Mexico and includes a broad area between the Nueces and Brazos Rivers. Several other perennial streams and numerous intermittent creeks transect the region, generally flowing from northwest to southeast. The northern zone shares its topographic characteristics with the Blackland Prairie, which gives way to relatively flat terrain towards the southern coast. The region has been divided into a number of smaller areas based on soil type (deep black clay to deep sand to shallow loam) and moisture characteristics, and differences in dominant vegetation (Black 1989:7). The Texan and Tamaulipan biotic provinces divide it northeast to southwest, respectively.

The project area is located within McAllister Park, in northeast Bexar County. Much of the present park is within a floodplain formed by two intermittent streams, Lorenz Creek and Mud Creek. Both are tributaries of Salado Creek, which drains into the San Antonio River. Soils in the project area are typically deep and composed mainly of clay and silt.

The major soils within this region consist of the Lewisville-Houston Black association, and include Trinity clays, Frio clay loams, Tarrant calcareous clays and Lewisville silty clays (Taylor et al. 1962:Sheet 29). Trinity and Frio clays and clay loams tend to occur on poor- to well-drained bottomlands (e.g., Mud Creek floodplain). These soils are developed from finetextured recent alluvium transported from nearby slopes. The thickness of the A horizon ranges from 108 to $190 \mathrm{~cm}$ (Taylor et al. 1962:113). Tarrant series calcareous clayey Lithosols have a dark grayish-brown color and develop over hard limestone in well-drained upland settings (e.g., upland settings overlooking Mud Creek) such as those found along the western edge of the project area along Jones Maltsberger Road. The thickness of the A horizon in these soils ranges from 14 to $32 \mathrm{~cm}$, and the texture ranges from clay to clay loam with numerous limestone fragments (Taylor et al. 1962:115). Lewisville silty clays have a dark grayish-brown color and develop under grassy vegetation on well-drained, nearly level to gently sloping terraces above floodplains (e.g., slopes bordering high terraces of Mud Creek). The texture of these soils ranges from light clay to clay loam to silty clay, with the clay content ranging from 32 to 55 percent. The A horizon in these soils can reach a thickness of between 43 to $105 \mathrm{~cm}$ (Taylor et al. 1962:113).

Historic land modification and grazing have severely impacted the local landscape creating a patchy mix of grasslands and woodlands (Riskind and Diamond 1986:29). Modern and prehistoric flora and fauna within the project area is transitional (Riskind and Diamond 1986:29) between the Balconian and the Tamaulipan biotic provinces.

\section{Previous Archaeological Research}

\author{
Rick C. Robinson
}

The project area lies between the Central Texas Plateau-Prairies and the South Texas Coastal Plain archaeological subregions (Hester 1989:2). The broad outlines of the general chronological and culture historic sequences established for these neighboring regions are also applicable to the project area (Collins 1995; Hester 1995; Johnson and Goode 1994; Prewitt 1981, 1983). Although some discrepancies still remain (Collins 1995; Johnson 1986; Johnson and Goode 1994), the commonly accepted regional chronology consists of the Paleoindian (11,000-6500 B.c.), the Early Archaic (6500-3500 B.c.), the Middle Archaic (3500-2300 B.C.), the Late Archaic (2300 B.C.-A.D. 750), and the Late Prehistoric (A.D. 750-1700; Johnson and Goode 1994) periods.

The rich archaeological record of Bexar County contains components and sites representative of each of these time periods. In addition, projects such as the recent investigations at Camp Stanley (Kibler et al. 1998; Scott et al. 1998), and previously investigated sites such as 41BX300 (Katz 1987), and 41BX228 (Black and McGraw 1985) provide a glimpse of the prehistoric archaeological sites expected within the project area. Based on these studies, it is possible to suggest that residential camps, lithic procurement, and specialized resource processing sites may all be encountered within the project area. The most likely locations for archaeological sites is near springs or on high terraces bordering nearby drainages (Potter et al. 1995:34-36). 
The project area itself is found within McAllister Park, a 714-acre parcel of land acquired by the city of San Antonio in 1966 . The purpose of this purchase by the city was to develop a recreational facility that would later become known as McAllister Park. In 1972, Anne Fox, working under the direction of the Texas Archeological Salvage Project, was given permission by the city of San Antonio Parks and Recreation Department to conduct a pedestrian survey to assess the presence of any archaeological sites within the park boundary. Three sites were identified on the east bank of Mud Creek. They consisted of a habitation site (41BX172), a lithic scatter (41BX173), and a lithic procurement site (41BX174, Fox 1973:3-5). The first two sites lie some 122 and $274 \mathrm{~m}$ to the south of the project area, respectively, along Bee Tree Drive within the park boundary. Site $41 B X 174$ is about 244 m east of site 41BX1412.

An additional survey relevant to the present project was conducted by CAR personnel between December 1976 and February 1977, at the request of the city of San Antonio. The purpose of the survey was to identify and record the cultural resources that would be impacted by future development of the city's wastewater treatment project (Fox 1977). The project area included portions of Mud Creek within and outside of the park. A number of prehistoric archaeological sites were recorded during the survey, including 41BX353, on the west bank of Mud Creek, and 41BX354, just north of Lockhill-Selma Road, also on Mud Creek (Fox 1977:12-15). Both sites appeared to be habitation sites containing scattered burned rock, lithic debitage, bifacial and unifacial tools, and projectile points (Fox 1977:12-15). Since then, no other archaeological investigations have been conducted within the park or its immediate vicinity.

The most directly relevant project conducted in the vicinity of the 41BX1412 is an intensive pedestrian survey and subsurface testing for potential cultural deposits along a proposed roadway extension through McAllister Park. The proposed extension was to impact two sections of the McAllister Park road system: the extreme western portion adjacent the park entrance at Jones Maltsberger, and the southern section at Starcrest Drive. The survey was conducted by CAR personnel between September 16 and October 21,
1999 , and eventually resulted in the discovery and testing of 41BX1412 (Tomka and Robinson 2000).

Three sites were identified and documented during this pedestrian survey $(41 \mathrm{BX} 1410,41 \mathrm{BX} 1411$, and 41BX1412). Site 41BX1410 is located approximately $200 \mathrm{~m}$ east of the park entrance at Jones Maltsberger. It covers approximately $162 \mathrm{~m}^{2}$. Three shovel tests (STs) were excavated in the site. Two of the shovel tests reached a depth of $10 \mathrm{~cm}$ below surface (bs), the third penetrated to $15 \mathrm{~cm}$ bs before reaching limestone. Four tertiary flakes and seven modern glass fragments were recovered from ST 1, Level $1(0-10 \mathrm{~cm}$ bs $)$. The low-density lithic scatter, and shallowness of the deposits indicated an ephemeral occupation. No further work was recommended at the site.

Site 41BX1411 is located approximately $75 \mathrm{~m}$ northeast of 41BX1410. It covers about $130 \mathrm{~m}^{2}$. A light scatter of flakes, cores, and an early reduction stage biface were observed on the surface. Three STs were excavated to a depth of $20 \mathrm{~cm} \mathrm{bs}$. A total of four tertiary flakes were recovered (ST 1, Level 2, n=1; ST 2, Level 2, n=1; and ST 3, Level 1, n=2). Given the low material recovery, the shallowness of the site, and the ephemeral nature of the occupation, no further work was recommended at the site.

The third site discovered during the 1999 survey is 41BX1412, the subject of this report. The site is located on an upland terrace on the south bank of Mud Creek and covers approximately $5,000 \mathrm{~m}^{2}$ (Figure 2). It is bisected by a sharp turn in Bee Tree Drive. The majority of the surface cultural materials noted during survey consisted of prehistoric chipped lithics, though a light veneer of historic material was scattered across the site. The analysis of a selected sample of the historic artifacts indicated that they date from the late-nineteenth and early-twentieth centuries. The densest prehistoric artifact surface scatter was south of Bee Tree Drive within a lightly wooded area (Figure 3). The density of material dropped rapidly to the south near a barbed wire fence at the southern boundary of the site. A total of 20 shovel tests and two $1 \times 1-$ $m$ excavation units (EUs) were dug to test the subsurface density and distribution of cultural materials. In subsequent discussions, these EUs will be identified by an Arabic numeral (i.e., EU 1 or EU 2). 
This page has been

redacted because it

contains restricted

information. 
The shovel tests reached a depth of between 40 and 60 $\mathrm{cm}$ bs. The two EUs were dug to $60 \mathrm{~cm}$ bs. A surface collection of artifacts was also carried out on site. A total of 779 prehistoric and 91 historic artifacts were recovered (Table 1). Historic artifacts tended to be concentrated in the upper two levels, while prehistoric artifacts seemed to be most common in deeper levels.

The analysis of the 779 prehistoric artifacts recovered from the site during testing indicated the presence of two potentially isolable components: 1) an Early Archaic component dating from the end of the period, and 2) a probable Paleoindian component of unknown age. The temporally diagnostic Early Archaic artifacts consist of a Uvalde point and five Guadalupe adzes. All of these specimens were recovered from the surface. The single artifact with Paleoindian affinities is a heavily patinated lanceolate dart point reworked into a drill (Tomka and Robinson 2000:Figure 9c). The relatively high percentage of patinated debitage from Level $6(74 \% ; n=35)$ compared to lower percentages in Levels 3-5 (ranging between $48 \%$ and 53\%) also suggested that the deeper materials may represent a distinct depositional component. And finally, the comparison of the patinated debitage collection with the technological characteristics of the unpatinated specimens suggested that the former contains a higher proportion of specimens removed during the late stages of biface manufacture (Tomka and Robinson 2000:21). These patterns suggest that although some degree of mixing of materials from the two components may have occurred, the differential patination of artifacts from the two components may be sufficient to permit their clear separation.

Given the possibility of the existence of Early Archaic and late Paleoindian components at 41BX1412, it was hoped that the site contained an isolable Uvalde component from which a solid behavioral association between Uvalde dart points and Guadalupe adzes could be established, as well as yield an isolable Paleoindian component of hitherto unknown age. Given the potentially significant research contribution the site could make to regional archaeological studies, CAR recommended that unless the roadway could be realigned, the impact of construction be mitigated through extensive excavations of the portion of the site within the proposed road extension. Members of the Department of Antiquities Protection of the Texas Historical Commission concurred with this recommendation (Appendix A). Following consultation with members of the Parks and Recreation Department of the city of San Antonio, it was decided that realignment of the proposed road was not feasible and that data recovery excavations should be carried out on the portion of the site to be impacted by construction. Following this decision, a data recovery plan was devised by CAR in collaboration with members of the Texas Historical Commission.

Table 1. Artifacts recovered from 41BX1412 during 1999 survey/testing

\begin{tabular}{|c|c|c|c|}
\hline Provenience & $\begin{array}{c}\text { Prehistoric } \\
\text { Artifacts }\end{array}$ & $\begin{array}{c}\text { Historic } \\
\text { Artifacts }\end{array}$ & Total \\
\hline General Surface & $\mathbf{2 8 4}$ & $\mathbf{3}$ & $\mathbf{2 8 7}$ \\
ST 1 & 32 & 3 & 35 \\
ST 2 & 1 & 3 & 4 \\
ST 3 & 7 & 3 & 10 \\
ST 4 & 1 & 2 & 3 \\
ST 5 & 3 & 7 & 10 \\
ST 6 & 6 & 5 & 11 \\
ST 7 & 4 & 3 & 7 \\
ST 8 & 7 & & 7 \\
ST 9 & 11 & & 11 \\
ST 10 & 15 & 4 & 19 \\
ST 11 & 5 & & 5 \\
ST 12 & 15 & 5 & 20 \\
ST 13 & 3 & 1 & 4 \\
ST 14 & 11 & 2 & 13 \\
ST 15 & 8 & 2 & 10 \\
ST 16 & 27 & 2 & 29 \\
ST 17 & 10 & 4 & 14 \\
ST 18 & 8 & 3 & 11 \\
ST 19 & 4 & 1 & 5 \\
ST 20 & 18 & & 18 \\
ST Totals & $\mathbf{1 9 6}$ & $\mathbf{5 0}$ & $\mathbf{2 4 6}$ \\
EU 1 & 65 & 11 & 76 \\
EU 2 & 234 & 27 & 261 \\
EU Totals & $\mathbf{2 9 9}$ & $\mathbf{3 8}$ & $\mathbf{3 3 7}$ \\
\hline Testing Totals & $\mathbf{7 7 9}$ & $\mathbf{9 1}$ & $\mathbf{8 7 0}$ \\
\hline
\end{tabular}




\section{Scope of Data Recovery Efforts at 41BX1412}

The data recovery plan focused on the following four goals: 1) recover a larger and more representative sample of the late Early Archaic lithic assemblage; 2) define and more extensively sample the possible Paleoindian component potentially present in the two deepest levels of the site; 3 ) locate and excavate features from both components; and 4) recover datable organic materials from the site.

To address the research goals of the project, and in consultation with the Texas Historical Commission, CAR recommended the use of two distinct levels of effort, depending on materials encountered. Site mitigation was to consist of the excavation of two $2 \times 2-m$ blocks in the central portion of the site in the vicinity of EUs 1 and 2 excavated during testing. The size of the blocks could be increased if the pace of excavation allowed. The two blocks would mitigate 2.2 percent of the artifact-rich portion of the site.

In addition, to ensure that an adequate search for buried Early Archaic and/or possible Paleoindian features was conducted, a backhoe was to be used to strip off two intersecting trenches in the most artifact rich portion of the site. The trenches were to be approximately three meters in width and $20-30 \mathrm{~m}$ in length. The striping was to occur in $1-5 \mathrm{~cm}$ increments from the surface to the bottom of the deposits (approximately 60 $\mathrm{cm} \mathrm{bs}$ ). If intact features and/or clearly identifiable living surfaces were encountered, additional handexcavated units would be positioned to explore these features/living surfaces. These exploratory investigations would involve either the excavation of individual 1 x 1-m units, multiple contiguous units, or small blocks, depending on the size of the feature(s). The primary goal of these units would be to recover ethnobotanical, chronometric, and artifactual remains associated with features. It was proposed that at least four, and up to six, additional $1 \times 1-m$ units would be dug in association with features discovered during stripping or the excavation of the two $2 \times 2$-m blocks.

Datable materials (i.e., charcoal) recovered from primary contexts, either associated with features or from clearly identifiable stratigraphic units, would be submitted for C-14 dating. Soil samples (two liters) would be collected from each level of a 1 x 1-m unit from each excavation block as well as any isolated excavation units. At least a portion (1.0-1.5 liters) of these samples would be floated to investigate the recovery of macrobotanical remains. In addition, soil susceptibility sample columns would also be collected from one $1 \mathrm{x}$ 1-m unit from each excavation block or isolated excavation unit. The soil susceptibility data would be used to identify the potential for buried surfaces at the site. Finally, in accordance with THC recommendations for data recovery projects, and in anticipation of Archeology Awareness Month, CAR proposed to incorporate a multifaceted educational component in the proposed work at 41BX1412.

\section{Field Methods and Laboratory Analyses}

\section{The Public Education Aspect}

In accordance with THC recommendations for data recovery projects, and in anticipation of Archeology Awareness Month, CAR incorporated an educational component in the archaeological work at 41BX1412. CAR provided an opportunity to members of the Southern Texas Archaeological Association (STAA) to participate in the excavations at the site. In response, nine STAA members took part in the week-long excavations, lending their experience and skills to the successful completion of the project (Figure 4). In addition, CAR invited college and middle school students to visit the site and observe excavations in progress. Four aspiring anthropology students from the Introduction to Anthropology course at San Antonio College visited the site and were given tours. Educational avenues, and opportunities for internships and employment in archaeology were discussed. Eighteen seventh graders from the Texas History Class of Mr. Mike Bailey from the Omar Bradley Middle School (Northeast Independent School District, San Antonio) visited the site as well (Figure 5). The steps in archaeological research were described to these students and their parents. In addition, CAR personnel prepared a summary of the fieldwork at 41BX1412. This summary was placed on the CAR web page where 
members of the public could learn about regional prehistory and the role of the public in archaeological explorations.

\section{Field Methods Employed}

To address the research goals of the project, and in consultation with the Texas Historical Commission, CAR employed two data recovery strategies. Two hand-excavated blocks were positioned in the central portion of the site in the vicinity of EU 1 and EU 2, dug during the 1999 site testing (Figure 6). The two blocks measured $2 \times 2 \mathrm{~m}$ and $2 \times 3 \mathrm{~m}$, respectively. The units within each block were designated by a Roman

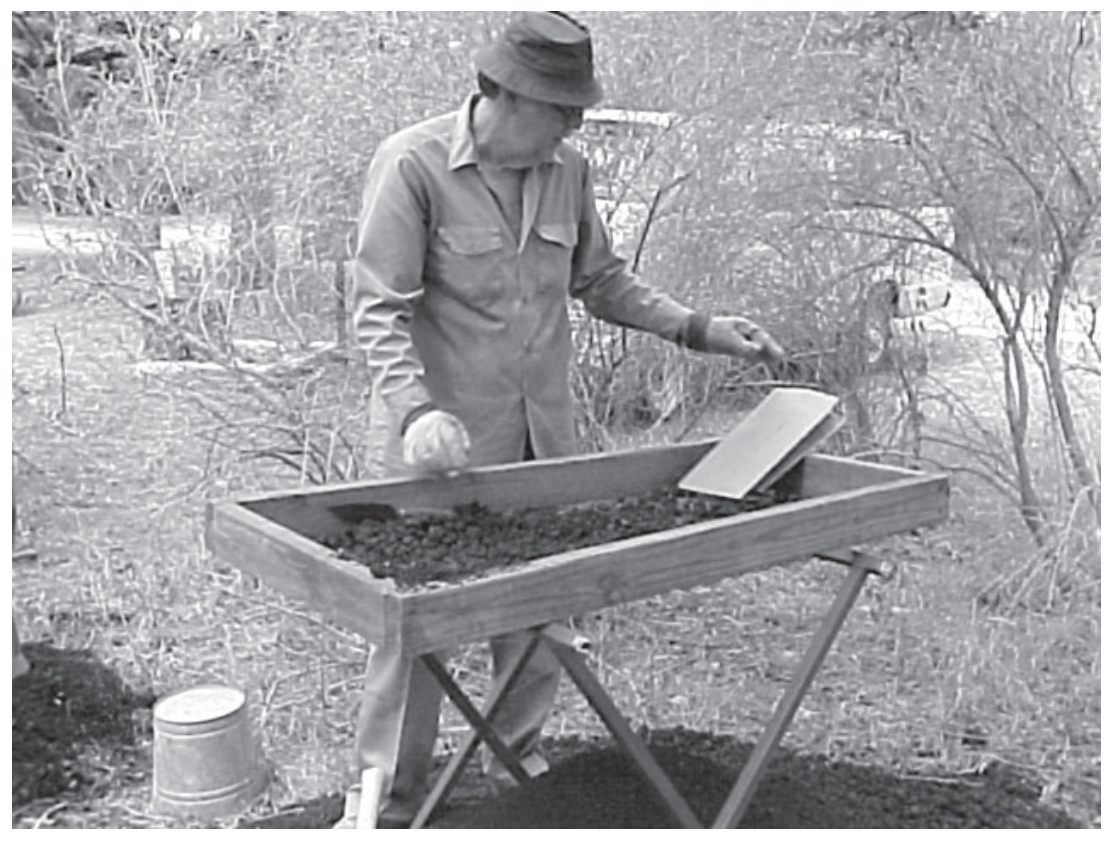

Figure 4. Volunteer from the Southern Texas Archaeological Association. numeral signifying the block (I or II) and an Arabic number for the individual unit (1-6) within each block (i.e., I-2, is Unit 2 in Block I). The $10-\mathrm{m}^{2}$ excavation resulted in the mitigation of approximately 2.5 percent of the artifact-richest portion of the site.

In addition, to ensure that an adequate search for buried features was conducted, a backhoe was used to

strip two trenches intersecting roughly in the center of the site. The north-south oriented trench was $27 \mathrm{~m}$ long and $3 \mathrm{~m}$ wide. The east-west oriented trench measured $12.5 \mathrm{~m}$ in length and $3 \mathrm{~m}$ in width. The striping occurred in $1-5 \mathrm{~cm}$ increments from the surface to the bottom of the deposits (varying between 50-80 $\mathrm{cm}$ bs). These mechanical excavations exposed an additional $118.5 \mathrm{~m}^{2}$ of the site.

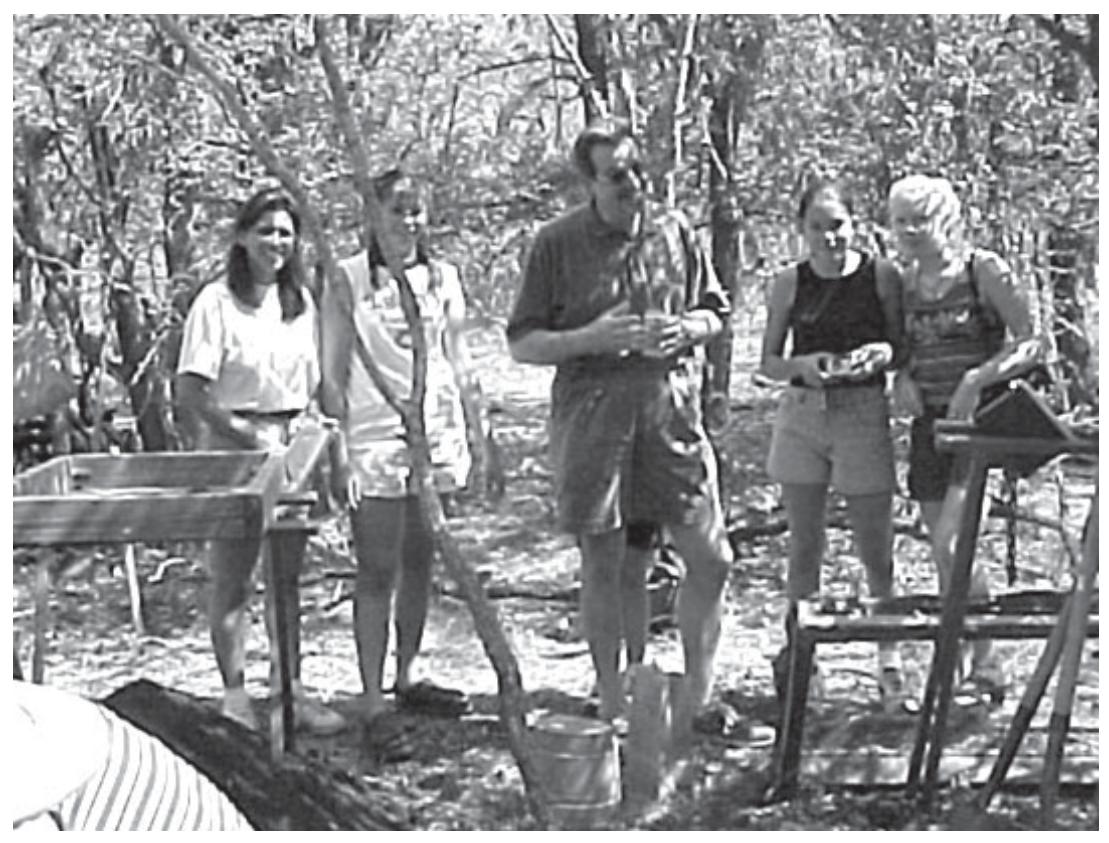

Figure 5. Middle school students from Omar Bradley Middle School, Northeast Independent School District, San Antonio, visiting the site.
Soil samples (two liters each) were collected from each level of a selected $1 \times 1-m$ unit in each of the two excavation blocks. In addition, soil susceptibility sample columns also were collected in 5-cm increments from one 1 x 1-m unit from each excavation block.

Artifacts recovered from the block excavations were processed (i.e., washed and catalogued) in the laboratory at CAR. The artifacts were analyzed using metric and parametric attributes and these were entered in Excel databases for statistical analyses. 


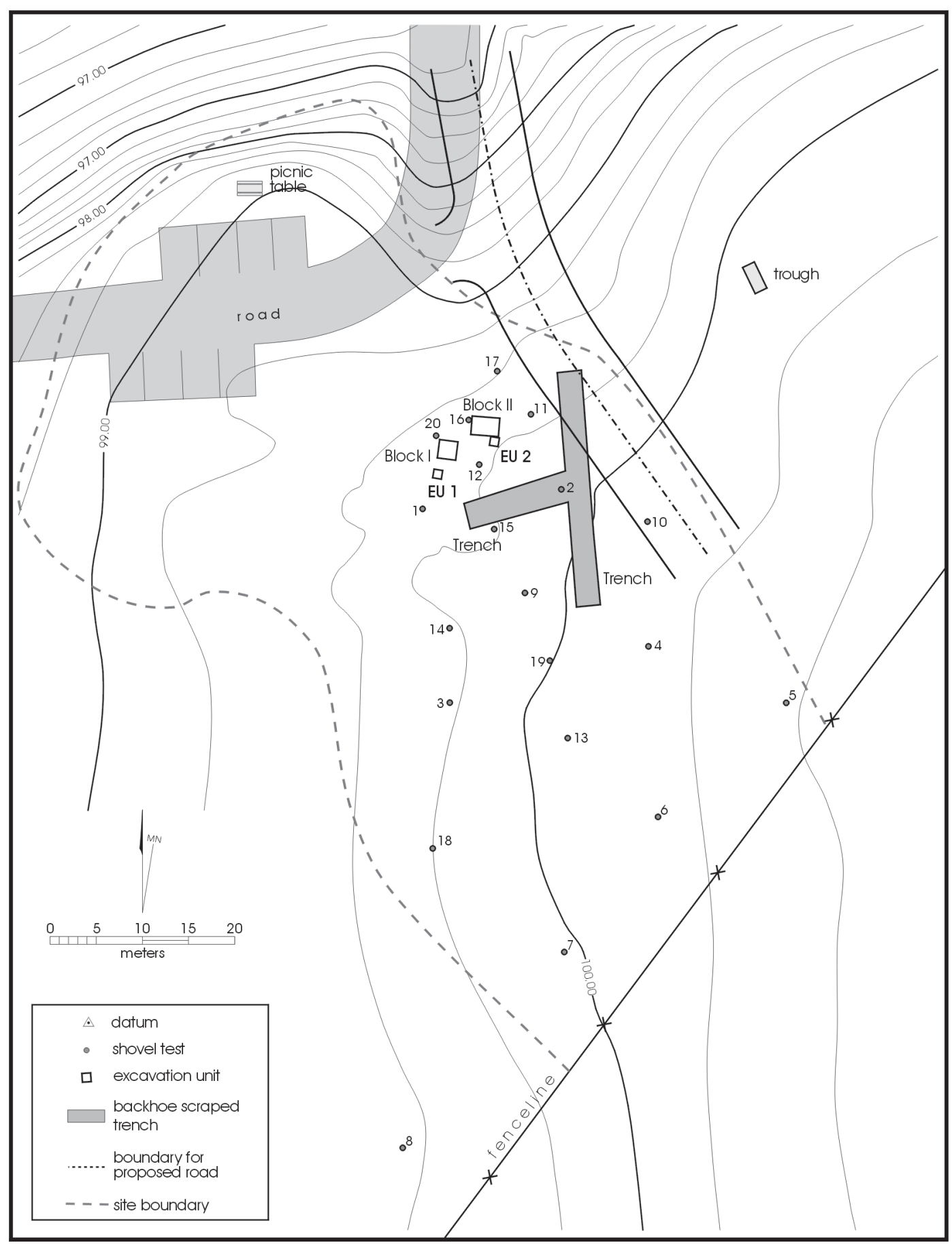

Figure 6. Site map of 41BX1412 showing shovel tests, hand-excavated blocks, and bladed areas. 


\section{Data Recovery Results}

\section{Stratigraphy}

The excavations of the two blocks revealed two soil zones extending across the area (Figures 7 and 8). The uppermost zone (Zone 1) consisted of a dark brown to dark gray (10YR $2 / 1$ to $10 \mathrm{YR} 2 / 2)$ relatively loose, and in parts, blocky soil. It ranged from $30-40 \mathrm{~cm}$ in thickness in Block I (Figure 7) and thinned to only 5$15 \mathrm{~cm}$ in Block II (Figure 8), located only three meters to the west. The zone was thickest $(40 \mathrm{~cm})$ along the western edge of Block I and continued thinning eastward across Block II to the point where it measured only approximately $5 \mathrm{~cm}$ in thickness at the eastern edge of the block.

Zone 2 consisted of blocky dark gray (10YR 3/2) clay loam across both blocks (Figures 7 and 8). It extended to roughly $80-85 \mathrm{~cm}$ bs in Block I and $45-50 \mathrm{~cm}$ bs in Block II. Calcium carbonate pebbles and nodules were present in the bottom portion of the profile in Block I but were less evident in Block II. Tabular limestone fragments were present at the bottom of both profiles as excavations reached the eroding limestone bedrock. This zone was nearly twice as thick in Block I compared to Block II. The contact between the two zones was relatively distinct but undulating.

The looser structure of the Zone 1 matrix, its gradual thinning across the portion of the site where the two blocks were located, and the undulating contact between the two zones, suggest that Zone 1 is either a zone truncated by road grading, or fill spread across the area to bring it to a particular grade. Neither of the two possibilities is out of the question since Bee Tree Drive is only approximately $20 \mathrm{~m}$ northwest of the blocks and the right-of-way (ROW) had previously been cleared of vegetation. Although the blocks were situated inside the remaining tree line, the vegetation consisted of brush that could have easily grown since the initial road construction. Discussions with Steve Uncapher of the Parks and Recreation Department revealed that it was likely that prior to the construction of the existing road, grading would have removed some of the loose matrix down to solid bedrock before the new road base and the asphalt top would have been laid down.

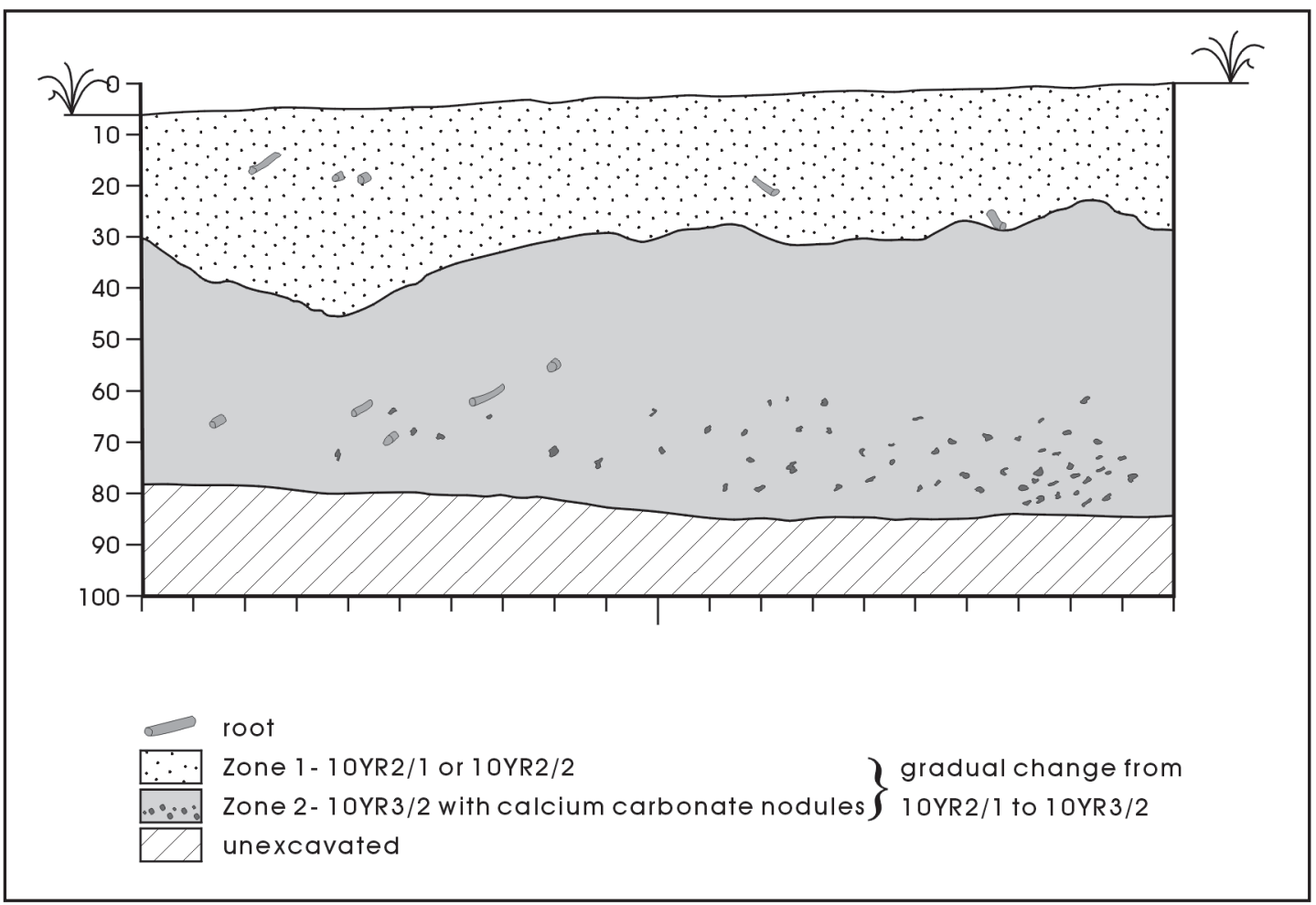

Figure 7. Profile of Block I, north wall of Units 1 and 2. 


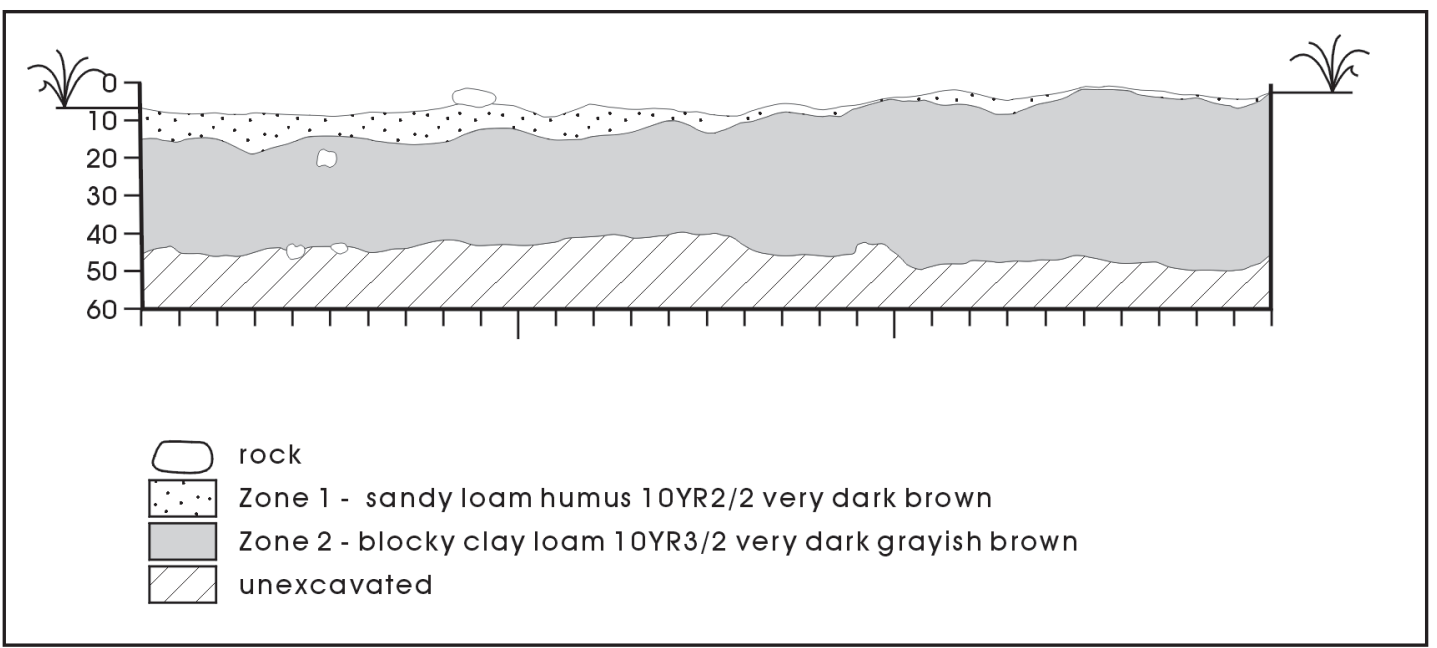

Figure 8. Profile of Block II, north wall of Units 1, 2, and 5.

\section{Features}

One of the goals of the excavation of the two intersecting scraped areas was the recovery of information on features and site structure. The recovery of burned rock fragments during testing phase excavations (Tomka and Robinson 2000:21) suggested that rock-lined hearths may be present in the upper $30 \mathrm{~cm}$ of the deposits. Neither the $118.5 \mathrm{~m}^{2}$ area exposed by blading nor the hand-excavated units uncovered intact, recognizable burned rock features. A single concentration of charcoal was identified in Unit II-3 beginning in Level 2 at a depth of $16 \mathrm{~cm}$ bs and continuing into Level 4, terminating at $38 \mathrm{~cm}$ bs. No pit outline was identified during excavation, and while two C-14 samples were removed from the concentration, it was not designed as a feature due to its poor definition.

\section{Radiocarbon Dating}

Two charcoal samples were collected from the concentration in Unit II-3. The charcoal samples came from 32 and $36 \mathrm{~cm}$ bs and were collected from near the middle and at the lower portions of the same concentration. Because no pit outline could be identified during excavation, it could not be determined in the field whether the concentration represented the remains of an intrusive recent hearth or a buried prehistoric feature. In addition to the two samples, small-carbonized wood fragments were recovered from a number of contexts, although both the size and recovery context of these specimens did not warrant their dating.

One of these two samples, the one derived from 36 $\mathrm{cm}$ bs, was submitted to Beta Analytic, Inc., of Miami, Florida for a radiocarbon assay. The radiometric assay produced a corrected date of $200 \pm 60 \mathrm{BP}$, which when calibrated yields a 1-sigma range of A.D. 16501950 (see Appendix B). This indicates that the charcoal is essentially modern in origin and represents a recent intrusion into the site.

\section{Artifacts Recovered}

Including chipped lithic artifacts, historic artifacts, burned rock, and snail shell, a combined total of 6,253 artifacts were recovered from 41BX1412 during both survey/testing and subsequent mitigation. Of these, a large majority $(n=5,232,84 \%)$ were recovered during mitigation. Prehistoric artifacts -chipped lithics and burned rock combined-constitute the bulk of the total collection $(\mathrm{n}=5,469,88 \%)$, while snail shells $(\mathrm{n}=578$, $9 \%)$ and historic artifacts $(\mathrm{n}=206,3 \%)$ are scarce.

A total of 5,232 artifacts were recovered from the two hand-excavated blocks and the mechanical excavations 
carried out during mitigation. They consist of prehistoric chipped lithics, historic artifacts, burned rock, and snail shells. Chipped lithics and fragments of burned rock, including heat spalls, constitute the largest quantity $(n=4,539,73 \%)$ of materials. Table 2 shows the distribution of these artifact classes by excavation unit. With the exception of the relatively higher density of historic artifacts in five units of Block II, no other clearly definable patterns can be noted. Table 3 shows the vertical distribution of these artifact categories. Historic artifacts and snail shells clearly decrease with increasing depth below surface. Few historic artifacts are found in Level $3(20-30 \mathrm{~cm} \mathrm{bs})$ and the two deepest historic artifacts are in Level 4 (30-40 cm bs).

Table 2. Distribution by excavation unit of artifact categories recovered from 41BX1412 during data recovery

\begin{tabular}{|c|c|c|c|c|c|}
\hline $\begin{array}{c}\text { Excavation } \\
\text { Unit }\end{array}$ & $\begin{array}{c}\text { Prehistoric } \\
\text { Lithics }\end{array}$ & $\begin{array}{c}\text { Burned } \\
\text { Rocks }\end{array}$ & $\begin{array}{c}\text { Historic } \\
\text { Artifacts }\end{array}$ & $\begin{array}{c}\text { Snail } \\
\text { Shells }\end{array}$ & Totals \\
\hline Mitigation-Surface & 14 & & & & 14 \\
I-1 & 382 & 155 & 12 & 86 & 635 \\
I-2 & 395 & 202 & 3 & 24 & 624 \\
I-3 & 338 & 124 & 4 & 58 & 524 \\
I-4 & 407 & 194 & 2 & 11 & 614 \\
II-1 & 309 & 211 & 23 & 87 & 630 \\
II-2 & 171 & 132 & 14 & 7 & 324 \\
II-3 & 203 & 119 & 21 & 16 & 359 \\
II-4 & 369 & 221 & 14 & 55 & 659 \\
II-5 & 196 & 111 & 6 & 114 & 427 \\
II-6 & 175 & 106 & 16 & 120 & 417 \\
E-W Trench & 5 & & & & 5 \\
\hline Totals & $\mathbf{2 9 6 4}$ & $\mathbf{1 5 7 5}$ & $\mathbf{1 1 5}$ & $\mathbf{5 7 8}$ & $\mathbf{5 2 3 2}$ \\
\hline
\end{tabular}

Table 3. Distribution by vertical provenience of artifact categories recovered from 41BX1412 during data recovery

\begin{tabular}{|c|c|c|c|c|c|}
\hline Level & $\begin{array}{c}\text { Prehistoric } \\
\text { Lithics }\end{array}$ & $\begin{array}{c}\text { Burned } \\
\text { Rocks }\end{array}$ & $\begin{array}{c}\text { Historic } \\
\text { Artifacts }\end{array}$ & $\begin{array}{c}\text { Snail } \\
\text { Shells }\end{array}$ & Totals \\
\hline Surface & 14 & & & & 14 \\
1 & 288 & 288 & 89 & 432 & 1097 \\
2 & 376 & 258 & 19 & 71 & 724 \\
3 & 661 & 344 & 5 & 37 & 1047 \\
4 & 745 & 249 & 2 & 17 & 1013 \\
5 & 383 & 138 & & 10 & 531 \\
6 & 280 & 160 & & 8 & 448 \\
7 & 191 & 119 & & 2 & 312 \\
8 & 26 & 19 & & 1 & 46 \\
\hline Totals & $\mathbf{2 9 6 4}$ & $\mathbf{1 5 7 5}$ & $\mathbf{1 1 5}$ & $\mathbf{5 7 8}$ & $\mathbf{5 2 3 2}$ \\
\hline
\end{tabular}




\section{Historic Artifacts}

\section{Anne A. Fox and Marybeth S. F. Tomka}

A total of 206 historic artifacts were recovered during the course of archaeological work at 41BX1412. A slightly higher number $(n=115)$ came from data recovery compared to initial testing efforts $(n=91)$. The 206 historic artifacts recovered from the site consist of fragments of wire $(n=101)$, miscellaneous unidentified metal $(\mathrm{n}=56)$, bottle and window glass fragments $(n=24)$, ceramics $(n=8)$, small barbed wire fragments $(\mathrm{n}=5)$, and a small number of additional artifacts. They include, aluminum ring tabs $(\mathrm{n}=2)$, metal buttons $(\mathrm{n}=2)$, unidentified plastic fragments $(\mathrm{n}=2)$, a shoe eyelet $(n=1)$, a shotgun shell $(n=1)$, a bottle cap $(n=1)$, a wire nail $(n=1)$, a fence staple $(n=1)$, and a fragment of an agricultural implement $(\mathrm{n}=1)$.

The majority of these historic artifacts are unidentifiable undiagnostic artifacts. However, a select number of items do offer a hint of the earliest age of the historic occupation of the site and its vicinity. Of the eight ceramic fragments, four are undecorated whitewares, two are stoneware fragments, one is a lead-glazed Mexican ware, and one is a plain undecorated specimen. Whitewares are generally an indicator of nineteenth century occupation on San Antonio sites. It was not until after the Civil War that American-made whitewares such as these became widely available in the San Antonio area (Tomka and Fox 1999a:29). The stoneware fragments are probably from cooking or storage vessels. Judging from their Albany type and Bristol glazes, these wares were probably locally made during the last quarter of the nineteenth century into the 1920s (Fox 1998).

The plain ceramic fragment is a small $1.5-\mathrm{cm}$ diameter sherd. It was recovered from Level $3(20-30 \mathrm{~cm}$ bs) of Unit II-5. The ceramic sherd has a fine paste with sand temper. It measures $4.62 \mathrm{~mm}$ in thickness and has a slight curvature. The exterior surface has been highly polished and could be considered a burnished self-slip. The interior surface is smoothed but not polished, possibly indicating that the sherd is from a jar or olla, and not a bowl. The core color is an even brown tone. However, the differing colors on the sherd's surfaces suggest that the vessel was fired in an oxidizing atmosphere and has been either subjected to post-firing heating or was fire clouded during firing. It is possible that the sherd is from a historic period vessel given that a historic component is present on the site. It also cannot be ruled out that the sherd may be part of the broad prehistoric Leon Plain series, however, no other artifacts in the assemblage, chipped stone or ceramic, have been found indicative of a Late Prehistoric component.

The single aqua-colored bottleneck fragment collected from the surface has no seam marks, suggesting that it is not machine-made. However, mold marks were erased during the formation of the neck and lip on panel bottles. This manufacturing technique was common at the end of the nineteenth and into the early twentieth centuries (1870-1917; Miller and Sullivan 1984).

No square nails were found. The single wire nail recovered from Level 2 of ST 3 may date from the very end of the nineteenth century to the present (Tomka and Fox 1999b:29).

The final temporally diagnostic artifact is a tooth from a harrowing machine used in a similar fashion as a plow and employed to breakup soil before planting. This type of agricultural implement was manufactured during the later part of the nineteenth and the early twentieth centuries (1880-1920; Waynne Cox, personal communication 2000).

\section{Prehistoric Artifacts}

A total of 3,743 chipped lithic artifacts was recovered from 41BX1412 during surface collections, shovel testing and test excavations, and data recovery (Table 4). The majority of these $(n=2,964,79 \%)$ came from data recovery. Although a sizable proportion $(n=313,8 \%)$ of the prehistoric chipped lithics was obtained from the surface during site testing and a few from mitigation, the bulk of the artifacts $(n=3,430,92 \%)$ came from below surface (Table 5).

The majority $(n=3,552,95 \%)$ of the collection consists of pieces of unmodified lithic debitage. The remaining specimens $(n=191,5 \%)$ are categorized into the following functional groups: 5 dart points, 4 perforators, 5 scrapers and/or scraper planes, 15 gravers, 
Table 4. Distribution of lithic artifact categories by STs, EU, and block excavation units (1999 survey/testing and 2000 data recovery)

\begin{tabular}{|c|c|c|c|c|c|c|c|c|c|c|c|}
\hline Provenience & $\begin{array}{l}\text { Dart } \\
\text { Point } \\
\end{array}$ & Perforator & Graver & Adze & $\begin{array}{c}\text { Scraper/ } \\
\text { Scraper Plane } \\
\end{array}$ & $\begin{array}{c}\text { Chopper/ } \\
\text { Wedge }\end{array}$ & $\begin{array}{l}\text { Misc. } \\
\text { Biface } \\
\end{array}$ & $\begin{array}{c}\text { Misc. } \\
\text { Uniface }\end{array}$ & Core & $\begin{array}{c}\text { Unmodified } \\
\text { Debitage } \\
\end{array}$ & Totals \\
\hline Testing Surface & 1 & 3 & 10 & 6 & 3 & 11 & 55 & 1 & 38 & 156 & 284 \\
\hline ST 1 & & & & & & & & & & 32 & 32 \\
\hline ST 2 & & & & & & & & & & 1 & 1 \\
\hline ST 3 & & 1 & & & & & & & & 6 & 7 \\
\hline ST 4 & & & & & & & & & & 1 & 1 \\
\hline ST 5 & & & & & & & & & & 3 & 3 \\
\hline ST 6 & & & & & & & & & & 6 & 6 \\
\hline ST 7 & & & & & & & & & & 4 & 4 \\
\hline ST 8 & & & & & & & & & & 7 & 7 \\
\hline ST 9 & & & & & & & & & & 11 & 11 \\
\hline ST 10 & & & & & & & & & 1 & 14 & 15 \\
\hline ST 11 & & & & & & & & & & 5 & 5 \\
\hline ST 12 & & & & & & 1 & & & & 14 & 15 \\
\hline ST 13 & & & & & & & & & & 3 & 3 \\
\hline ST 14 & & & & & & & & & & 11 & 11 \\
\hline ST 15 & & & & & & & & & & 8 & 8 \\
\hline ST 16 & & & & & & & 1 & & & 26 & 27 \\
\hline ST 17 & & & & & & & 2 & & & 8 & 10 \\
\hline ST 18 & & & & & & & & & & 8 & 8 \\
\hline ST 19 & & & & & & & & & & 4 & 4 \\
\hline ST 20 & & & & & & & & 1 & & 17 & 18 \\
\hline ST Totals & 0 & 1 & 0 & 0 & 0 & 1 & 3 & 1 & 1 & 189 & 196 \\
\hline EU 1 & & & 3 & & & & 1 & & & 61 & 65 \\
\hline EU 2 & & & 1 & & & & 2 & 2 & & 229 & 234 \\
\hline EU Totals & 0 & 0 & 4 & 0 & 0 & 0 & 3 & 2 & 0 & 290 & 299 \\
\hline $\mathrm{I}-1$ & & & & & & & 1 & 1 & & 380 & 382 \\
\hline $\mathrm{I}-2$ & 1 & & & & & & 3 & 1 & & 390 & 395 \\
\hline I-3 & & & & & 2 & & 2 & 2 & & 332 & 338 \\
\hline I-4 & & & & & & & 4 & & & 403 & 407 \\
\hline II-1 & 1 & & & & & & 2 & & & 306 & 309 \\
\hline II-2 & & & & & & & 1 & & 1 & 169 & 171 \\
\hline III-3 & & & & & & & 1 & & 1 & 201 & 203 \\
\hline II-4 & & & & & & & 2 & & & 367 & 369 \\
\hline II-5 & & & & 1 & & & & 2 & & 193 & 196 \\
\hline II-6 & & & 1 & & & & 1 & & 2 & 171 & 175 \\
\hline E-W Trench & & & & & & & 2 & 1 & 2 & & 5 \\
\hline Mitigation Surface & 2 & & & & & & 4 & 1 & 2 & 5 & 14 \\
\hline Mitigation Totals & 4 & 0 & 1 & 1 & 2 & 0 & 23 & 8 & 8 & 2917 & 2964 \\
\hline Grand Totals & 5 & 4 & 15 & 7 & 5 & 12 & 84 & 12 & 47 & 3552 & 3743 \\
\hline
\end{tabular}

7 adzes, 12 choppers/wedges, and 47 cores (Tables 5 and 6). Tool function was determined by low-powered (20-80x) micro-wear analysis. Twelve unifacially flaked artifacts are classified as indeterminate unifaces, and 84 bifaces and biface fragments are classified as a miscellaneous bifaces. Metric dimensions and observational attributes of the tools recovered from 41BX1412 are presented in Appendix C. 
Table 5. Distribution of lithic artifact categories recovered from STs, EUs, and block excavation units by level (1999 survey/testing and 2000 data recovery)

\begin{tabular}{|c|c|c|c|c|c|c|c|c|c|c|c|}
\hline Provenience & $\begin{array}{l}\text { Dart } \\
\text { Point } \\
\end{array}$ & Perforator & Graver & Adze & $\begin{array}{c}\text { Scraper/ } \\
\text { Scraper Plane }\end{array}$ & $\begin{array}{c}\text { Chopper/ } \\
\text { Wedge }\end{array}$ & $\begin{array}{l}\text { Misc. } \\
\text { Biface }\end{array}$ & $\begin{array}{c}\text { Misc. } \\
\text { Uniface }\end{array}$ & Core & $\begin{array}{c}\text { Unmodified } \\
\text { Debitage } \\
\end{array}$ & Totals \\
\hline Surface & 3 & 3 & 10 & 6 & 3 & 11 & 59 & 2 & 40 & 176 & 313 \\
\hline Level 1 & & & 2 & & & 1 & 7 & 3 & 4 & 380 & 397 \\
\hline Level 2 & & 1 & & 1 & 2 & & 5 & 2 & 1 & 444 & 456 \\
\hline Level 3 & 2 & & & & & & 7 & 3 & 2 & 747 & 761 \\
\hline Level 4 & & & 2 & & & & 1 & 1 & & 850 & 854 \\
\hline Level 5 & & & 1 & & & & 3 & & & 425 & 429 \\
\hline Level 6 & & & & & & & 1 & 1 & & 314 & 316 \\
\hline Level 7 & & & & & & & 1 & & & 190 & 191 \\
\hline Level 8 & & & & & & & & & & 26 & 26 \\
\hline Totals & 5 & 4 & 15 & 7 & 5 & 12 & 84 & 12 & 47 & 3552 & 3743 \\
\hline
\end{tabular}

\section{Dart Points}

Five dart points have been found at the site. Of these, four were encountered during data recovery excavations (Table 4). The five projectile points from the site consist of a single Uvalde projectile point (Turner and Hester 1993), three Pedernales proximal fragments, and an untypeable medial fragment (Figure 9). The single Uvalde point (Figure 9a) was recovered from the surface. It has an expanding stem, a concave to U-shaped base, strong shoulders, a triangular blade, and slightly ground stem edges. An impact scar is present on the tip and one ear is broken. Morphologically, the specimen also fits other Early Archaic points that have been lumped into the broad "Early CornerNotched" category (e.g., early corner-notched, Variety 2 from the La Jita Site [Hester 1971:Figure 10m-s; Sorrow et al. 1967:Figure 12a-c]).

Two of the Pedernales fragments (Figure 9b-c) are from Level 3 (20-30 cm bs) of units I-2 and II-1, respectively. Both appear to have been broken in use. The third Pedernales point, a medial fragment (Figure 9d), and the untypeable medial specimen (Figure 9e), appear to have been broken post-depositionally. The latter is a dart point preform found on the surface following the backfilling of the E-W trench. Its stem was broken by machinery immediately below the neck. No Pedernales points were found during the previous work at the site.

\section{Perforators}

Four perforators have been identified in the collection. All four were recovered during the testing of the site (Table 4). Three of the four are surface finds (Table 5). The single buried specimen came from Level 2 $(10-20 \mathrm{~cm}$ bs) of ST 3.

Based on the thickness and width of their working tips, three are classified as reamers -tools employed in enlarging holes. One specimen is a drill employed in making, rather than simply enlarging, existing holes.

The three reamers form a morphologically homogeneous group. All are made on thick hard hammerstone flakes by unifacially flaking the broad working tip on the distal end of the blank. One of the three specimens is made on a heavily patinated recycled hard hammerstone flake. The working tip is shaped by the alternate unifacial flaking of the tool's edges. The manufacture flake scars are unpatinated. The two other reamers also lack patina. Two of the reamers were recovered from the surface, while the recycled specimen comes from Level $2(10-20 \mathrm{~cm}$ bs) of ST 3.

The single drill from the site was found on the surface at the edge of the tree line adjacent Bee Tree Drive. It represents a dart point recycled into a drill (Figure 9f). The entire artifact is heavily patinated suggesting that the reworking occurred soon after the original 


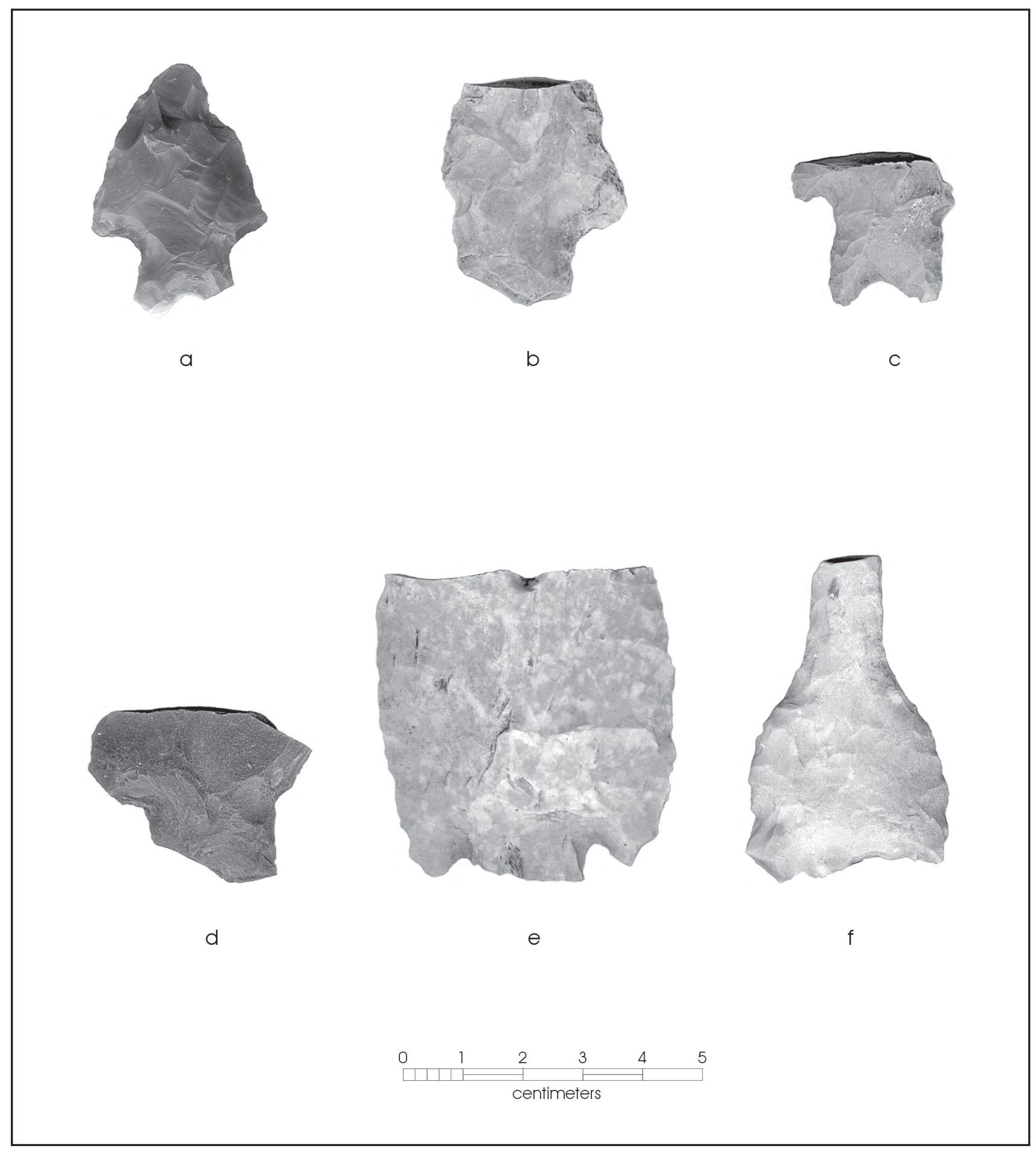

Figure 9. Temporal diagnostic artifacts recovered from 41 BX1412 during mitigation. a) Uvalde point; b-d) Pedernales points; e) untypeable point; f) drill. 
manufacture of the specimen. The two long base thinning flakes, the execution of the flaking on the faces of the specimen, the wide $(34 \mathrm{~mm})$ and thick $(9 \mathrm{~mm})$ yet lenticular cross-section of the specimen, and remnants of grinding on the partially re-flaked stem edges and base, are consistent with Paleoindian flaking characteristics (see Clovis points, Howard 1990). In summary, the morphological and flaking characteristics and the heavy patina present on the specimen suggest strong affinities to a Paleoindian projectile point.

\section{Gravers}

The majority $(n=10)$ of the 15 gravers from the site are surface finds. All but one of them was found during the testing of the site (Table 4). The five specimens from excavated contexts come from Levels 1 , 4, and 5 (Table 5).

Based on the degree of retouch that has gone into their manufacture, they can be divided into three categories: four are expedient gravers that represent the utilization of fortuitous sharp corners of flake blanks; ten were made by the minimal retouch of one or more of the edges of a blank to create a pointed graving tip; and one specimen has one formal and a minimally retouched working tip. The formal graver tip was made by substantially flaking the edge of the blank to define a sharp graving tip.

Two of the expedient gravers are heavily patinated tertiary flake fragments employed as gravers. Multiple burin scars off the graving tips indicate repeated resharpenings. The remaining two expedient gravers are secondary hard hammerstone flake fragments with sharp, pointed corners employed as gravers. One of these has two repeatedly resharpened (i.e., burinated) graver tips (Lot No. 128-208).

The minimally retouched gravers are made on hard hammerstone flake blanks. The working tips are commonly created by deeply notching one or two areas adjacent a natural protrusion along the flake's edges. In general, elongated flakes were chosen as blanks ( 8 of $10,80 \%$ ), although two are made on short and wide flakes. On one of these two, the graver tip was made by minimally retouching the corner of the distal end and the adjacent lateral edge of the blank (Tomka and Robinson 2000:Figure 9f). This manufacture technique, and the resulting morphology, are reminiscent of "spurred end scrapers" commonly found in Folsom assemblages (Boldurian 1990:Figure 42).

The final graver has two working tips. The formal tip is made by the heavy retouch of the distal end of a secondary flake blank into a pointed working tip. The minimally retouched working tip was made by retouching an additional edge adjacent the corner of the flake. The formally manufactured working tip was broken in manufacture, while the minimally retouched later graver tip is complete.

\section{Adzes}

Seven adzes have been recovered from the site (Table 4). Six of them are surface finds from testing (Table 5). The single buried specimen comes from Level 2 (10-20 cm bs) of Unit II-5 (Table 5). Of the seven specimens, six are identified as Guadalupe adzes (Black and McGraw 1985), and one is a minimally retouched adze that shares some morphological affinities with the type. Guadalupe adzes are common in Bexar County, but their distribution is much broader encompassing the San Antonio and Guadalupe River and portions of drainages along the Balcones Escarpment and into the Coastal Plains region, and even extending along the middle reaches of the Rio Grande Valley. Although few specimens have been excavated from well-dated and undisturbed contexts, the available data from the Granberg II Site (Hester 1979; Hester and Kohnitz 1975) and the Panther Springs Creek Site (Black and McGraw 1985:146) suggest that Guadalupe tools date to the later part of the Early Archaic, between approximately 3600-3400 B.C. (see also Turner and Hester 1993).

Of the seven specimens recovered, two are complete, four are distal fragments, and one is a proximal specimen. The single buried specimen is a use-broken proximal fragment. One of the two complete specimens (Lot No. 128-168) is a finished, heavily rejuvenated tool (Figure 10a). It has a working face (bit spine-plane; Brown 1985) angle of 64 degrees. The second complete adze was never finished and was discarded due 

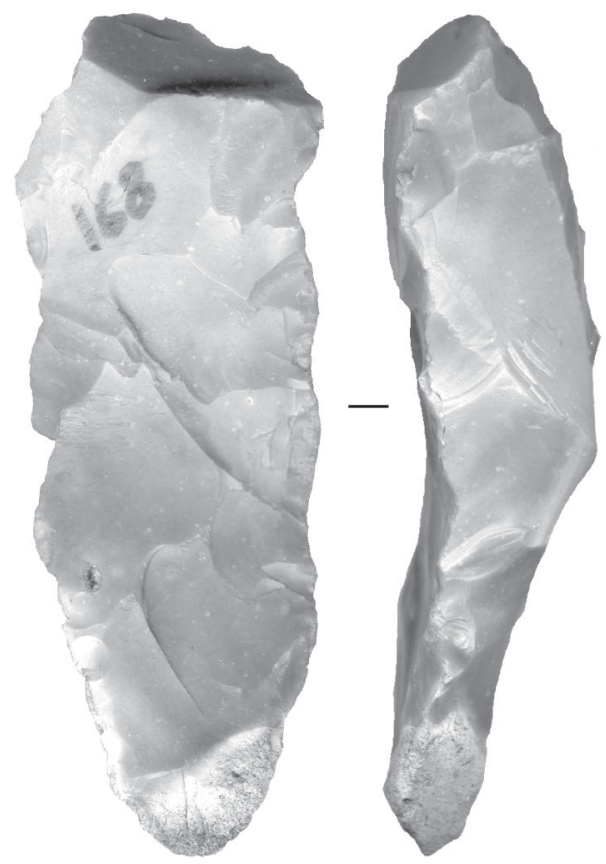

a
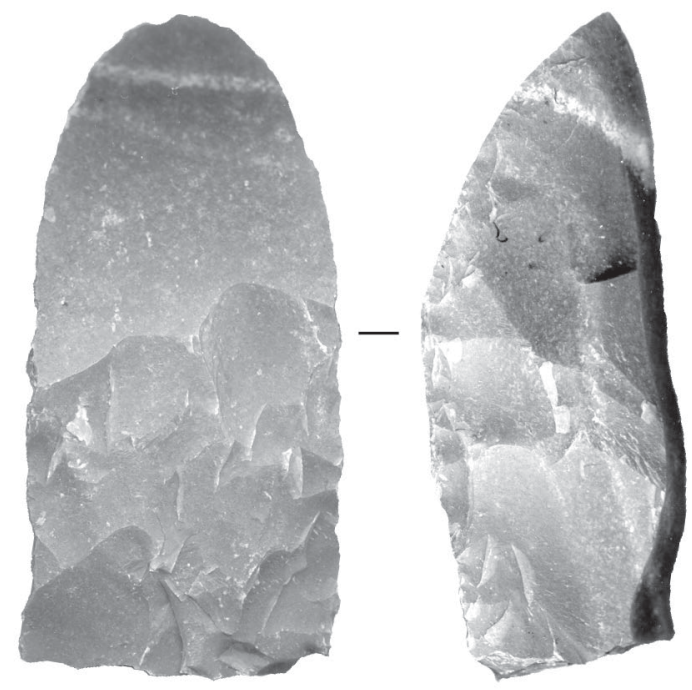

b

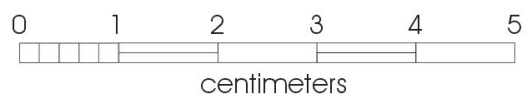

Figure 10. Guadalupe adzes from 41BX1412.

in part to the fact that the working edge never reached the desired morphology, and perhaps the angle desirable for this tool form. One of the four distal fragments recovered appears to have been a functional tool broken in use (Figure 10b). It has an acute working face angle of 40 degrees. This figure is very much at the lower extreme of the working edge angle distribution (see Brown 1985).

The remaining three Guadalupe adze distal fragments are manufacture-failed specimens. All three have a tri-faceted cross-section and the flake-patterning characteristic of Guadalupe adzes, however, only one, the distal fragment, has the well-formed single-faceted bit characteristic of the type. In the case of the other two, the working face exhibits multiple flake removals that appear to have been designed to create a face angle that approximated that of a finished tool. If so, the final face angle and morphology would have been accomplished by the removal of a single large flake, consistent with Model No. 2 described by Black and McGraw (1985:Figure 31).

One of the four distal adze fragments is a surface collected minimally retouched specimen. It is made on a short but wide, single-faceted hard hammerstone flake. The intersection of the large single-faceted platform and the bulb of percussion form the rounded bit characteristic of Guadalupe adzes. A series of three short flakes were used to remove and round the otherwise sharp ridge created by the intersection of the bulbar surface and platform face. A single large removal, 
originating from the bulbar face, created the steep working face angle morphology (68 degrees) characteristic of the tool. The ventral face of the tool, that would otherwise be flaked, is a flat surface formed by an imbedded fracture plane. The bulb of percussion forms one of the lateral surfaces, while the corticate dorsal face of the parent flake forms the second lateral surface. The proximal end of the tool was broken in use, most likely in the process of prying and bending the tool towards the material being worked. Minimal retouch is present along one edge of the tool to shape the specimen for hafting. Use-wear, in the form of step fracture scars and polish, is present along the working edge. Localized patches of polish also are present on the ventral and bulbar face of the tool; this wear is the product of hafting.

\section{Scrapers and Scraper Planes}

Three end scrapers and two scraper planes are in the assemblage (Table 4). Three of these were recovered from the surface during testing (Table 5). Two additional specimens came from Level 2 (10-20 cm bs) of Unit I-3.

Based on the degree of retouch employed in tool manufacture, two of the three end scrapers are formal tools. Secondary hard hammerstone flake blanks were used to make the tools. On one of the two formal tools, the distal working edge is tangential to the longitudinal axis of the flake blank. On the other specimens, all of one side and the distal and proximal end of the flake blank have been retouched to shape the tool and its working edge. The third end scraper is a small hard hammerstone flake employed as an expedient scraper.

Two primary macro-flakes (124 x $97 \times 40 \mathrm{~mm}$ and 109 x 58 x $49 \mathrm{~mm}$ ) have one and two unifacially retouched working edges, respectively. Irregularly spaced micro-flake scars are present on the ventral faces of both tools along the unifacially retouched working edges. Some localized areas of polish are also notable on the ventral faces of these specimens immediately adjacent the working edges and on the protruding bulbs of percussion. The ventral face polish and micro-flaking indicate that these rather large tools were hand-held scraper-planes most likely used in woodworking.

\section{Choppers and Wedges}

Twelve specimens have been identified as either choppers or wedges; they were recovered during testing (Table 4). All but one of these is a surface find. The single buried specimen comes from Level $1(0-10 \mathrm{~cm}$ bs) of ST 12 (Table 5). All specimens have one or two bifacially flaked working edges and at least one of these edges is cortex-backed. All twelve are complete and range in weight from 1,072 to 146 grams with an average weight of 578.5 grams (s.d. $=295.7$ g). Assuming that an efficient chopper needs to be relatively heavy, while weight is less critical for a wedge, it is likely that at least the three lightest specimens $(146,313$, and 316 grams, respectively) were used primarily as wedges. On the other hand, all other specimens may have been employed as both choppers and wedges. Use-wear, in the form of step fracturing, light edge-rounding, and localized polish on flake scar ridges and the working edges, is common on all but the three lightest specimens. No use-wear could be identified on these three specimens at the low magnification range (20-80x) employed in this study. Of the twelve tools, nine ( $82 \%)$ have a single working edge, and three have two working edges.

\section{Miscellaneous Unifaces}

Eight unifacially retouched flake fragments and four complete flakes are classified in this category. Four of them come from testing, while eight were found during data recovery (Table 4). Eight of the unifaces are from Levels 1-3, only two are from deeper levels (Table 5).

The fragmentary specimens lack use-wear and they are too small to determine blank and/or tool morphology. Nonetheless, at least four of the blade-like flake fragments appear to be proximal segments of either end scrapers or combination end scrapers. One of the complete miscellaneous unifaces is a large secondary flake (66 × 49 × $16 \mathrm{~mm}$; Lot No. 128-40) that has one unifacially retouched corner and two isolated flake removals from the distal end. It appears to have been an intended end scraper, but was rejected prior to completion. The second complete miscellaneous specimen (Lot No. 150-4) appears to have had a well-flaked distal end reminiscent of end scrapers. However, 
extensive flaking of the ventral face has removed much of the original working edge and little of the original morphology remains. The third miscellaneous uniface (Lot No. 196-7), made on a tertiary flake, also appears to represent a bifacially reworked uniface. The fourth complete miscellaneous uniface (Lot No. 2033 ) is a proximal tertiary flake fragment with some flaking along one edge and its distal end. Flaking is irregular on the distal end where the thick break face may have prevented the successful shaping of the working edge.

\section{Miscellaneous Bifaces}

A total of 84 bifacially flaked artifacts could not be classified into functional categories because they do not exhibit use-wear, morphologically do not resemble existing tool forms, and/or have been broken prior to completion. Only twenty-five (30\%) of the specimens are from buried contexts (Table 4). Of these twentyfive, $19(76 \%)$ are from Levels 1-3 (Table 5). Of the 84 miscellaneous bifaces, $25(30 \%)$ are complete, 24 (29\%) are proximal, $14(17 \%)$ are distal, $10(12 \%)$ are edge or wedge segments, 10 (12\%) are medial, and one is a longitudinal fragment. Forty-two (71\%) of the 59 incomplete specimens have been broken during manufacture. Four specimens (two distal and two medial) were broken during use, and two appear to have been post-depositionally broken. The causeof-break could not be determined in the case of the additional eleven specimens. Based on stage of reduction, 54 (64\%) are early reduction specimens characterized by thick cross-sections, cortex on one or both faces, deep hard hammerstone flake scars, and sinuous bifacial edges. Of the remaining 30 bifaces, 23 specimens $(27 \%)$ are middle reduction stage bifaces characterized by somewhat thinner cross-sections, total lack of cortex, and more linear bifacial edges. Four fragmentary specimens are either late reduction stage or more likely portions of functional tools. However, the specimens are too fragmentary to classify them into functional categories. The final three bifaces could not be classified due to their small size. The core/blank used in the manufacture of the bifaces could be determined for only 30 specimens. Flake cores are slightly more common $(n=17,57 \%)$ than pebble cores.

Two complete early reduction stage bifaces (Lot No. 128-20 and Lot No. 128-252) and two early reduction stage proximal fragments (Lot No. 128-95 and 196-8) have overshot flake scars. Overshot flake removals are a systematically employed strategy in thinning Clovis blanks (see Collins 1999:46). However, overshot flakes from the Gault Site (41BL323) shown to the senior author by Michael B. Collins (Texas Archeological Research Laboratory) clearly had been removed from middle to late reduction stage bifaces rather than the early stage specimens in this collection. However, the removal of overshot flakes earlier in the reduction may be even more effective in thinning the blanks and also may afford the opportunity to correct any manufacture problems derived from removal mistakes. An additional early reduction stage proximal biface fragment (Lot No. 128-111) exhibits technological characteristics reminiscent of Clovis technology. This specimen was broken during the removal of a longitudinal base-thinning flake. This base thinning strategy is commonly employed in thinning Clovis preforms and has been observed on a number of specimens from the Gault Site (M. B. Collins, personal communication 1999; see also Callahan 1979).

\section{Cores}

Forty-seven cores have been recovered from the site; of these, $39(83 \%)$ were found during testing (Table $4)$. The majority of the 47 specimens $(n=40,85 \%)$ are surface finds (Table 5). Level $1(0-10 \mathrm{~cm} \mathrm{bs})$ contained four specimens and no cores were found below Level 3 (20-30 cm bs). Unidirectional cores constitute the bulk of the specimens $(n=26,55 \%)$, followed by multidirectional $(n=12,26 \%)$ and bidirectional $(n=9,19 \%)$ specimens. The number of flake removals per core ranges from as few as one $(n=2)$ to as many as $23(\mathrm{n}=1)$, the mean number of removals is $6.6($ s.d. $=4.2)$ per core. If we consider that one to two flake removals may be necessary to assess the quality of the chert, it is likely that five specimens can be classified as tested cores. Although eight cores have eleven or more flake removal scars, judging from the average size of the cores, none of the specimens are exhausted.

\section{Unmodified Debitage}

A total of 3,552 unmodified lithic debitage was obtained from the site. The bulk of the collection is from the two block excavations $(n=2,912,82 \%)$, eight percent 
$(n=290)$ came from excavation units dug during testing, five percent $(\mathrm{n}=189)$ came from shovel tests, and four percent $(n=161)$ came from random surface collection (Table 4). The highest quantity of debitage occurs in Levels 3 and 4 of the site (Table 5).

Overall, the lithic debitage collection is dominated by tertiary specimens $(n=3,054,86 \%)$. Corticate debitage, consisting of secondary $(\mathrm{n}=443,12.5 \%)$ and primary $(\mathrm{n}=55,1.5 \%)$ specimens, constitutes only about 14 percent of the total collection. The high proportion of decorticate debitage from the site suggests that the late stages of tool manufacture, perhaps in combination with tool rejuvenation, are the main activities contributing to the collection. The high proportion of fragmentary debitage $(n=3,032,85 \%)$ may be due to a number of factors including, the fine-grained raw material, the predominance of relatively thin soft-hammer removals, and/or traffic following discard. Angular debris is infrequent $(n=33,1 \%)$ in the debitage collection.

Finally, the analysis of debitage types in the collection indicates that a total of $1,710(48 \%)$ could not be categorized and $97(3 \%)$ are angular debris. Of the remaining 1,745 , the large majority $(n=1,103,63 \%)$ are core/platform preparation specimens. Debitage derived from bifacial reduction constitutes the second highest percentage $(\mathrm{n}=554,32 \%)$, while unifacial tool manufacture debitage $(\mathrm{n}=42,2 \%)$ contributed only a small proportion. Thirty ( $2 \%)$ notching flakes, and a single burin flake have been identified in the collection.

One of the interesting factors about the debitage collection derived from biface reduction is that it contains six overshot flakes such as the two illustrated in Figure 11. As mentioned previously, overshot flake removals are a systematically employed strategy in thinning Clovis blanks (see Collins 1999:46). While the overshot flakes shown to the senior author by M. B. Collins were clearly middle to late reduction stage removals, Harry J. Shafer (Texas A\&M University) indicated that some overshot flakes from the Gault site were removed during the early stages of reduction (H. J. Shafer, personal communication 2001).

The vertical distribution of debitage recovered from the site during the different stages of work, has a unimodal pattern (Table 5). Debitage frequencies increase from surface through Level 4 and decrease there after through Level 8. This pattern suggests that a single occupation zone is present at the site. However, given that during data recovery excavations the volume of matrix excavated within each level of each unit varied slightly, it was decided to recalculate adjusted debitage counts by 0.1 cubic meter for the ten units. Volumetrically adjusted debitage counts from Blocks I and II suggest that rather than a simple battleship-shaped plot, the frequencies of debitage seem to have a bimodal pattern (Figure 12). The first peak occurs in Level 4 in both blocks while a second smaller peak seems to be present in Level 6 of Block I.

This finding seems to support the suggestion for the existence of two components at the site, derived from the analysis of the mean and standard deviation of debitage maximum dimensions obtained during testing (Tomka and Robinson 2000:20). Under normal depositional contexts, the smaller the surface area of a flake, the greater the likelihood that it will readily work its way down a profile. Inversely, the larger the surface area of the specimen, the more likely that it will remain on, or close to, the original living surface, or it will have a slower movement rate. Given this general relationship, it is expected that the mean size of the debitage should decrease as one progresses below an original living and/or depositional surface.

The mean size of the debitage obtained in the general surface collection is $62 \mathrm{~mm}$ (s.d.=22.8). In EU 1, excavated during testing, the largest mean debitage size is found in Level 1, and mean debitage size decreases with depth (see Levels 4 and 5 in Table 5). In EU 2, dug during testing, the largest mean debitage size is found in the top two levels and mean debitage size decreases steadily in the next two levels. Significantly, however, mean debitage sizes increase again in Levels 5 and 6 to size ranges similar to those in the upper two excavation levels. This pattern in debitage mean maximum dimension suggests the presence of two occupation/depositional surfaces. It confirms the upper depositional surface at or near the present ground surface and indicates the presence of a second depositional surface either between $40-50$ or $50-60 \mathrm{~cm}$ bs.

To explore whether this size distribution pattern also holds for the larger debitage collection obtained during 

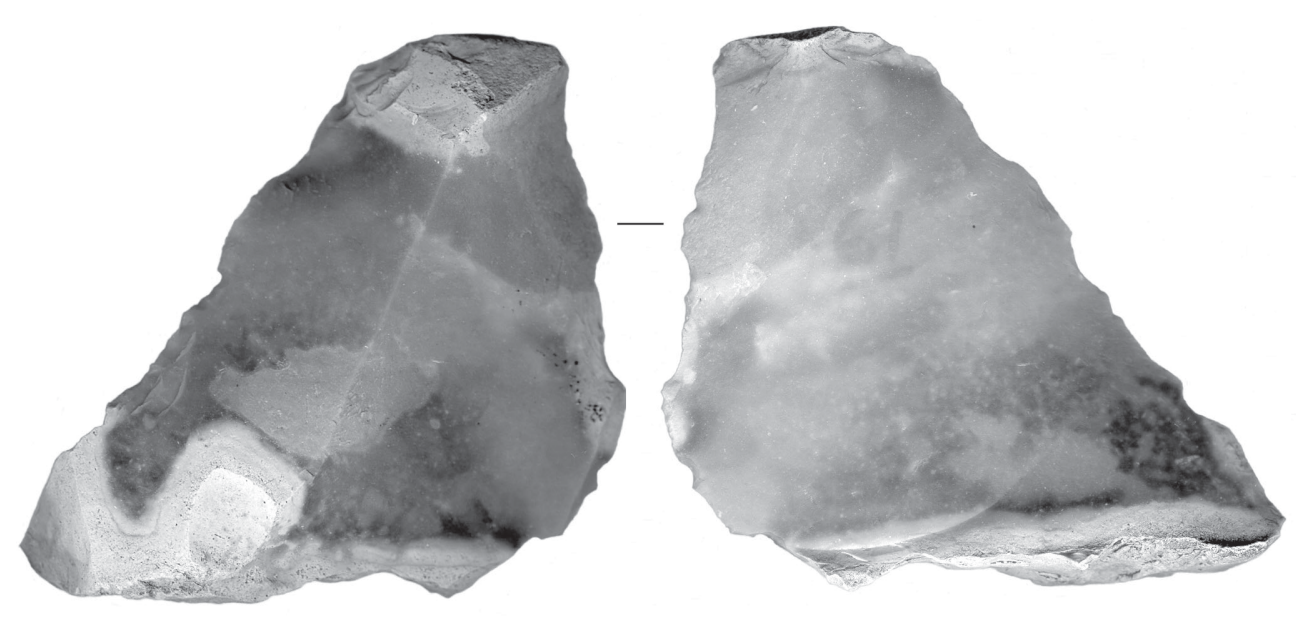

a
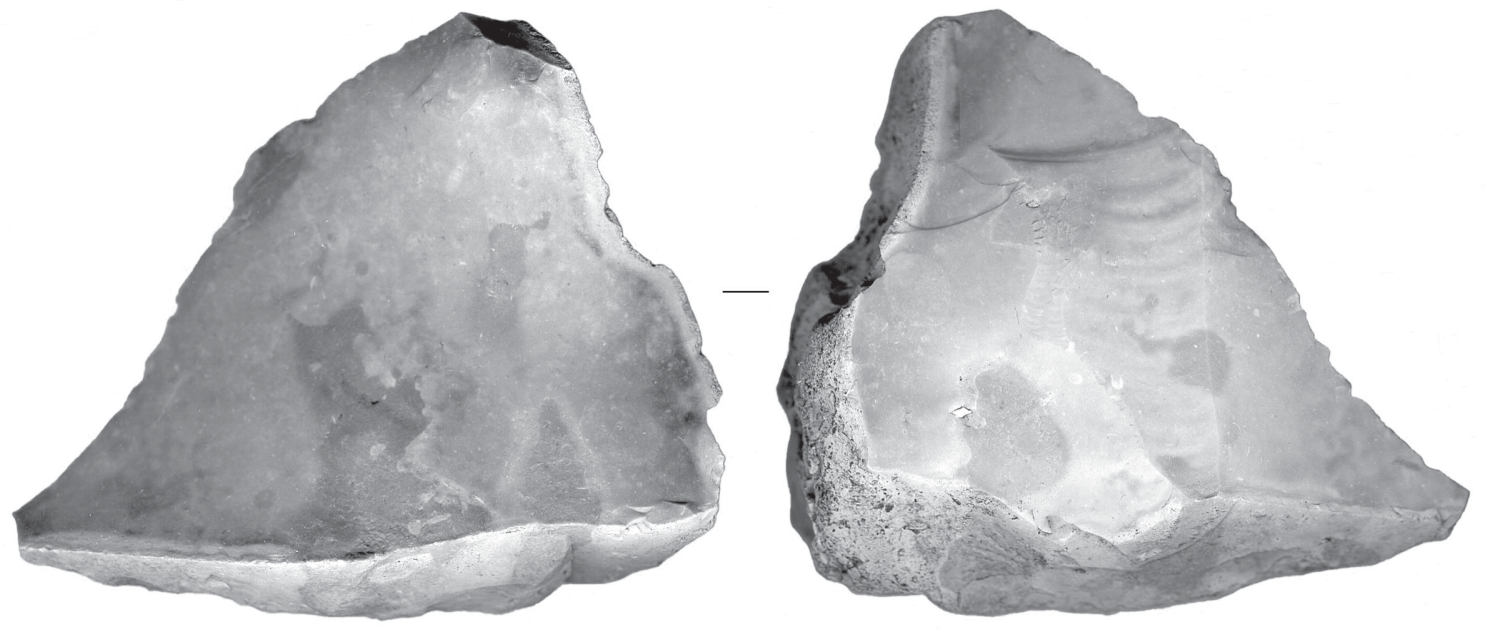

b

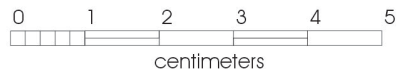

Figure 11. Examples of overshot flakes from 41BX1412.

data recovery, the mean maximum dimension of all debitage was calculated by level and block. Figure 13 indicates that mean maximum debitage dimensions are highest at surface and gradually decrease through Level 5 in both blocks. However, in both blocks, there is a slight increase in mean maximum dimensions in Level 6, followed by a decline in Block I, the only block with samples from Levels 7 and 8 . This trend seems to corroborate the preliminary finding based on the smaller testing phase samples, and reaffirms the possibility that a deeper second depositional unit may exist at the site.

During the testing phase excavations, and subsequent laboratory processing, it was observed that a proportion of the unmodified debitage was heavily patinated. The patina is of a white to light tan color. To further investigate the possible existence of the deeper 


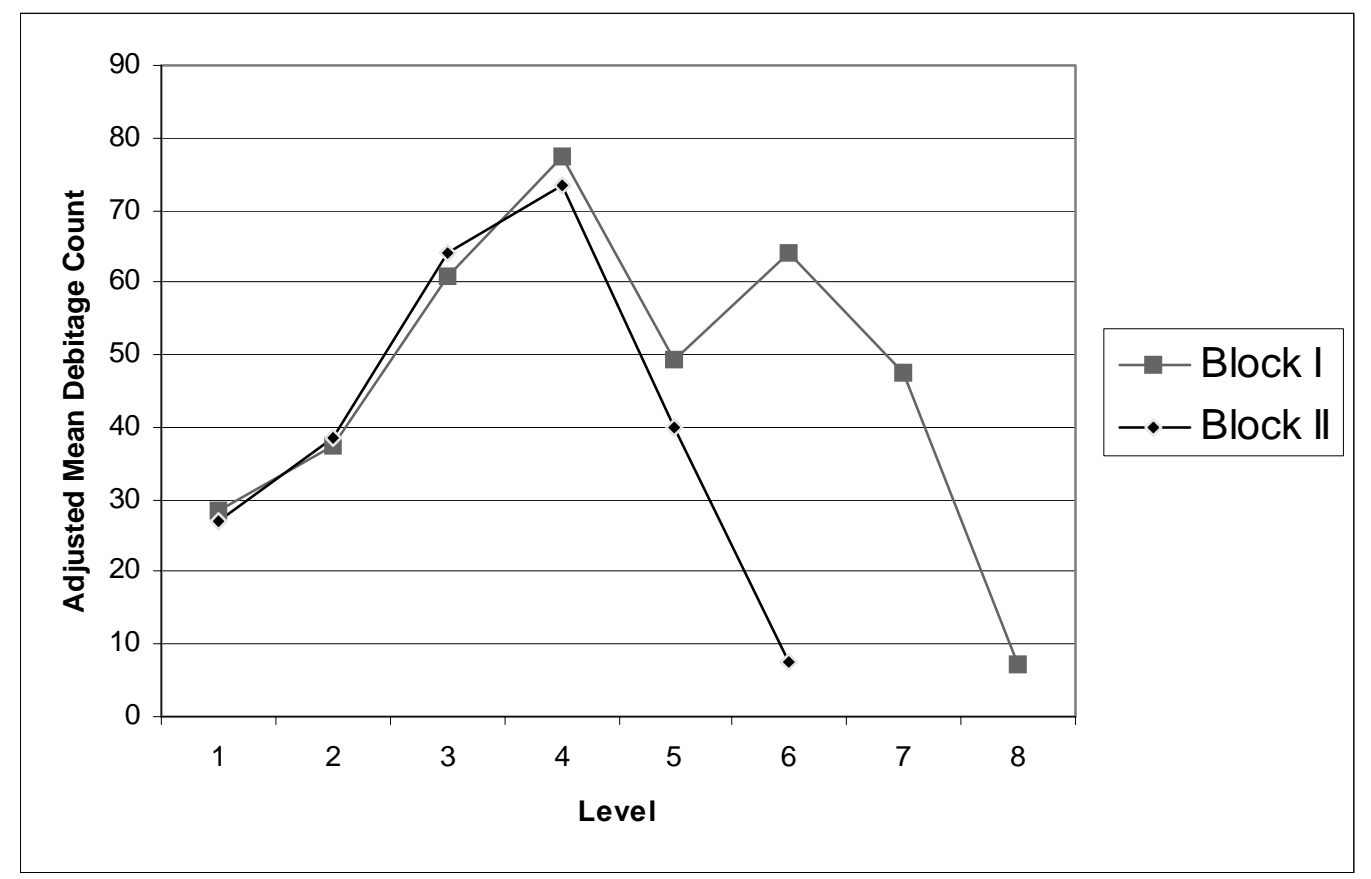

Figure 12. Distribution of adjusted unmodified debitage counts by $1 \mathrm{~m}^{3}$ level and block.

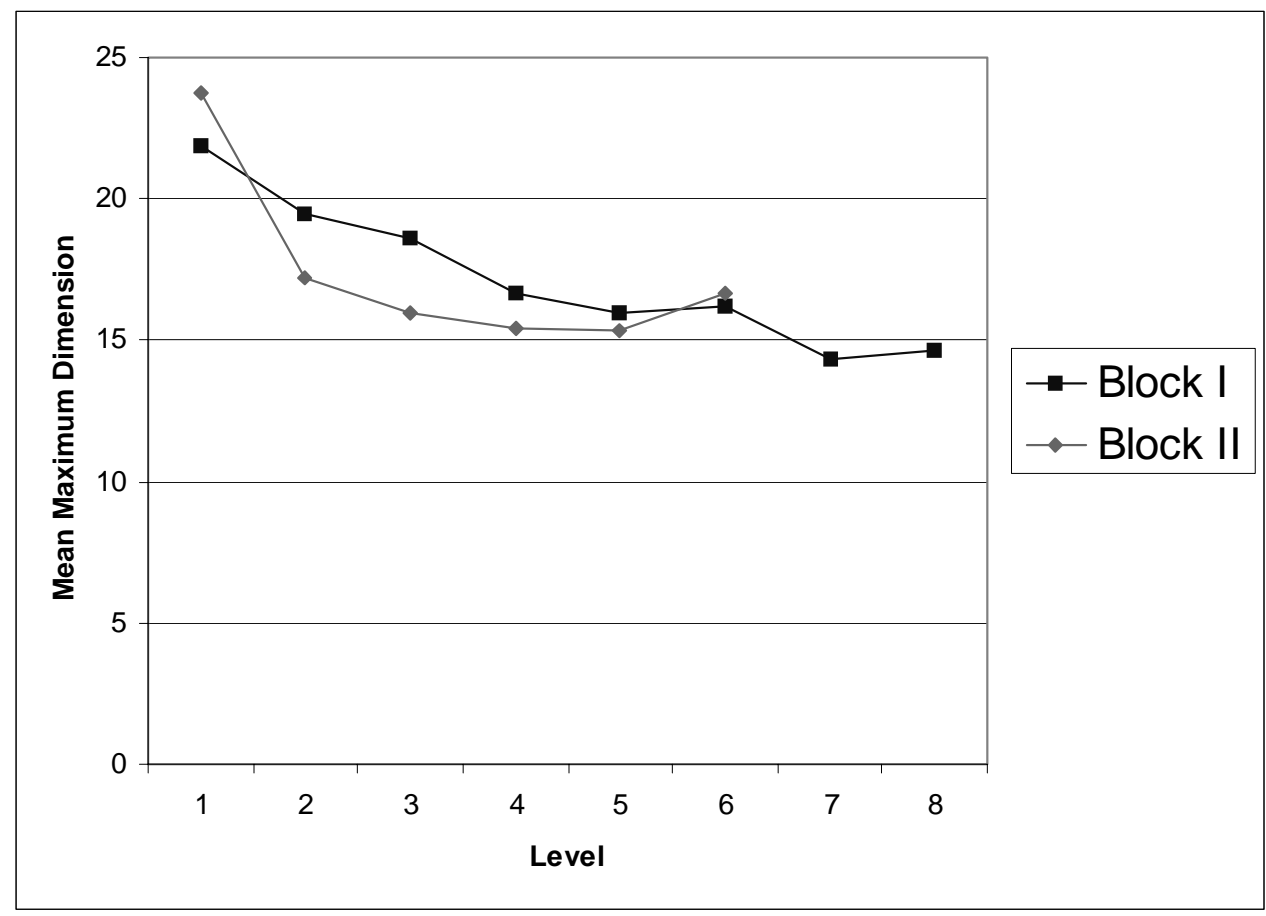

Figure 13. Plot of mean maximum dimensions by level and block of debitage recovered during data recovery. 
depositional surface by independent means, it was decided to investigate the patterning in debitage patination by level within the STs and the two EUs. A total of 479 debitage pieces were recovered from the twenty STs and two EUs. The frequency of patination is relatively low among the debitage recovered from the surface of these units $(\mathrm{n}=15,27 \%)$ and from Levels $1(n=104,17 \%)$ and $2(n=76,36 \%)$. About half of the debitage from Levels 3-5 (Level 3, $\mathrm{n}=99,52 \%$; Level 4, $\mathrm{n}=106,53 \%$; Level $5, \mathrm{n}=44,48 \%$ ) is patinated. In contrast, nearly three-fourths of the debitage from Level $6(n=35,74 \%)$ is patinated. Of the 35 patinated specimens from Level 6, $28(80 \%)$ are from EU 2, indicating that the pattern is heavily skewed by this EU. Overall, the distribution of patinated debitage confirms the existence of a deep depositional zone in Level $6(50-60 \mathrm{~cm}$ bs). The presence of patinated debitage in the upper levels may be the result of bioturbation and/or the upward movement of materials due to argilliturbation processes within clay soils (Waters 1992:299-300).
The percentage of patinated debitage was also calculated for the ten excavation units that form the two blocks excavated during data recovery. Figure 14 indicates that in both blocks the proportion of patinated debitage increases with increasing depth below surface. In general, only about one-third of the debitage from the two highest levels (Levels 1 and 2) is patinated while about one-half of the samples from Levels 3 and 4 are patinated. On the other hand, more than three-fourths of the debitage collection from the two deepest levels of Block I is patinated. This increase in the percentage of patinated debitage parallels the trend noted in the smaller testing phase sample. Overall it seems to corroborate the suggestion that a second, deeper depositional zone exists at the site. An alternative explanation for the patterns is that patination is a process that increases with increased depth.

A total of 203 patinated and 276 unpatinated pieces of debitage were recovered from the twenty STs and

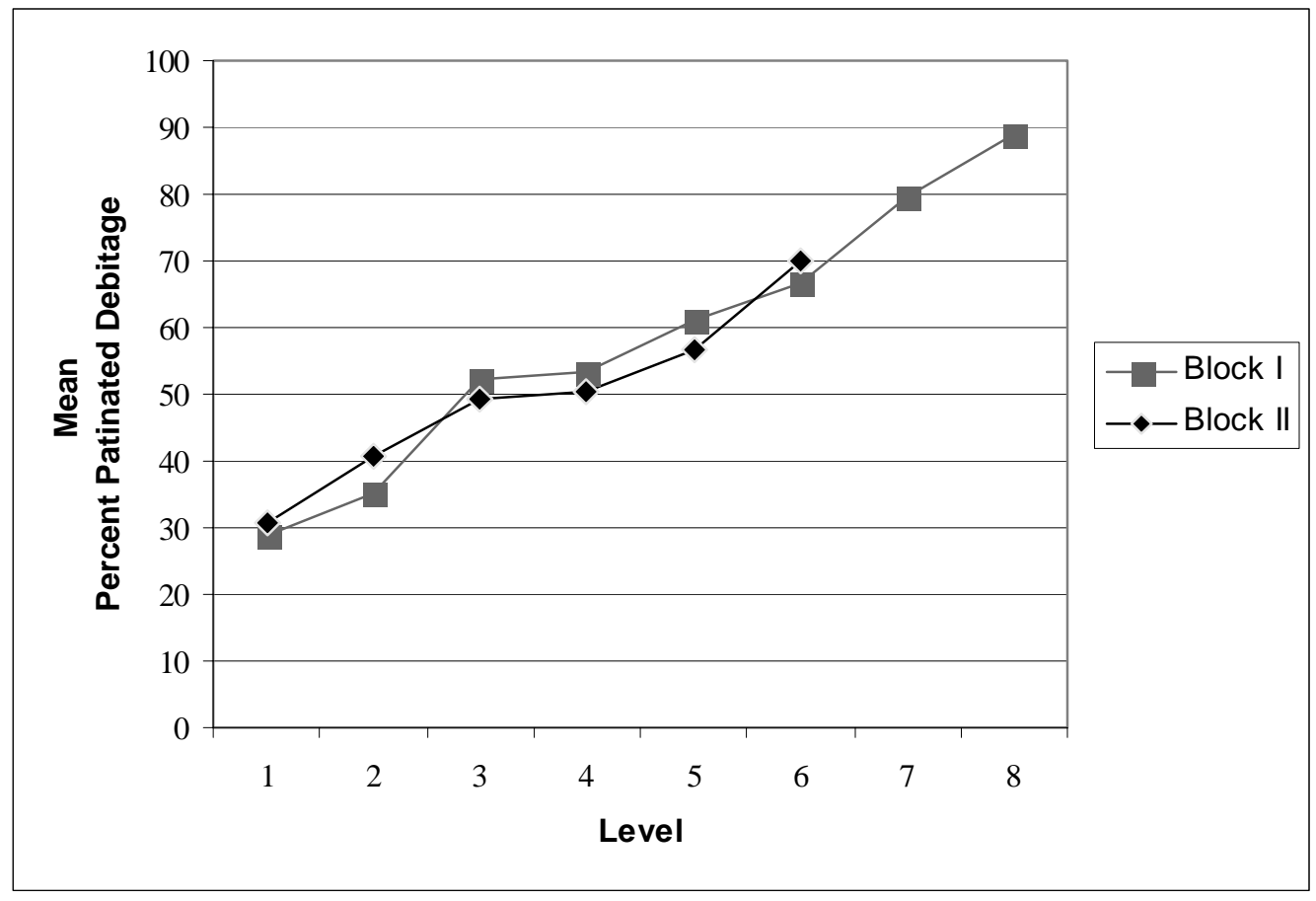

Figure 14. Distribution by level and block of the percentage of patinated debitage obtained during data recovery. 
two EUs. The comparison of debitage attributes within the patinated and unpatinated subgroups indicates a few notable differences. In terms of debitage completeness, the principal difference between the two subsets lies in the higher proportion of angular debris within the unpatinated collection $(n=21,8 \%)$ versus the patinated specimens $(n=8,4 \%)$. This difference may reflect the predominance of hard hammerstone flake removals in the unpatinated debitage versus the use of soft hammer billet flaking in the patinated debitage collection. This pattern, may in turn, indicate higher proportions of late reduction stage removals in the patinated collection. These conclusions are supported by trends in platform faceting. While 57 percent $(n=48)$ of the patinated platform-bearing flakes have two or more platform facets, only 39 percent of the unpatinated platform-bearing flakes have two or more platform facets. A similar conclusion can be drawn from the cortex category data. While 85 percent $(n=173)$ of the patinated debitage is tertiary, only 73 percent $(n=200)$ of the unpatinated debitage collection is entirely decorticate. In terms of flake type patterning, the main difference between the two subgroups is in the slightly higher percentage of bifacial reduction debitage (e.g., manufacture, thinning, rejuvenation) in the patinated debitage collection (26\%) compared to the unpatinated debitage $(22 \%)$.

The subtle but important technological differences between the patinated and unpatinated debitage collections obtained during testing also appear to suggest that two possible depositional surfaces or cultural zones are present at the site. One depositional surface appears to have been on, or near, the present ground surface, and the other may be buried in Level 4 , or deeper.

Although platform characteristics were not recorded in the debitage collections obtained during data recovery, some differences between the patinated $(n=1,511)$ and unpatinated $(n=1,406)$ debitage do seem to exist in this collection. Ninety-three percent $(n=1,405)$ of the patinated debitage is entirely decorticate, and 39 percent $(n=266)$ of the classifiable debitage $(n=680)$ can be categorized as biface reduction debitage. On the other hand, 87 percent $(n=1,223)$ of the unpatinated debitage is entirely decorticate and thirty percent $(n=206)$ of the classifiable specimens $(n=670)$ can be considered to derive from bifacial reduction. Although these differences in the technological characteristics of patinated and unpatinated debitage are less dramatic than in the smaller testing phase collection, they do follow similar trends. That is, a higher proportion of the patinated debitage seems to derive from late stage biface manufacture compared to the subset of unpatinated debitage.

\section{Fire-cracked Rocks and Heat Spalls}

Although no features were identified in the STs and EUs excavated during testing, scattered fragments of burned rock and numerous heat spalls were recovered. Most of the fire-cracked rock (FCR) noted on the surface, and recovered from excavation, was five $\mathrm{cm}$ in diameter or smaller. The tabulation of FCR and heat spalls by level from STs and EUs excavated during testing indicates that Levels 1-3 have the highest frequencies (Level 1, $\mathrm{n}=51$; Level 2, $\mathrm{n}=26$; Level 3, $\mathrm{n}=36$ ). Their frequencies decrease significantly in the bottom three levels (Level 4, $\mathrm{n}=21$; Level 5, $\mathrm{n}=10$; Level 6, $\mathrm{n}=7$ ). These patterns indicate that thermal facilities employing heated rocks may have been present on site and they may have been concentrated in the upper $30 \mathrm{~cm}$ of the deposits.

Given the differences in the volume of archaeological deposits excavated by level during data recovery, burned rock counts were adjusted by volume to provide a more accurate representation of the relative quantities of these materials by depth. The volumetrically adjusted burned rock fragment and heat spall counts by block suggest that rather than a simple battleship-shaped plot, the distributions are quite different in the two blocks (Figure 15). While there is a smaller peak in burned rock counts in Level 3 of Block I, the highest counts occur in Level 6. On the other hand, in Block II the two highest counts of burned rock occur in Levels 1 and 3. Burned rock counts decrease steadily in the deeper levels of the block. Interestingly, this pattern suggests significantly different depositional histories for the two blocks. 


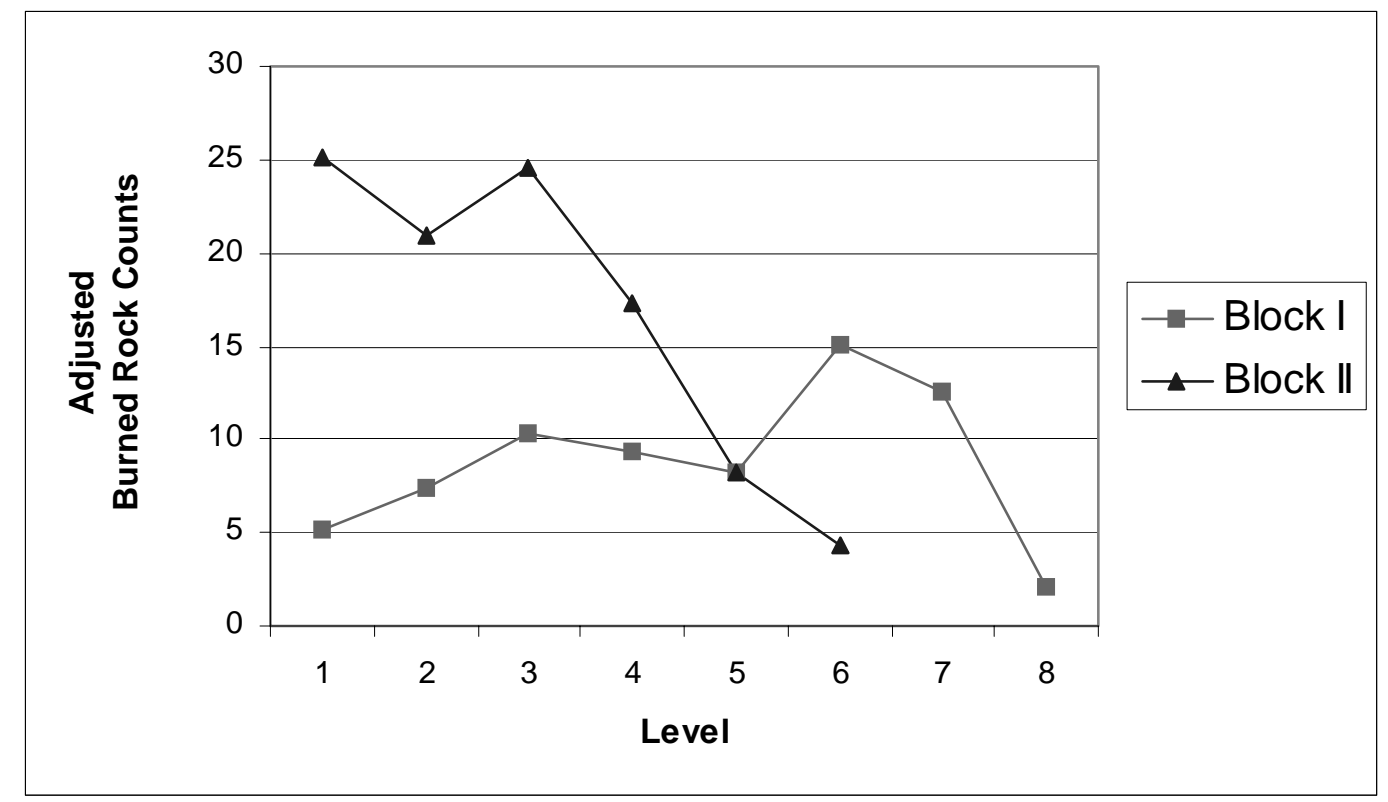

Figure 15. Distribution of adjusted burned rock counts by $1 \mathrm{~m}^{3}$ level, both blocks combined.

\section{Magnetic Sediment Susceptibility Testing}

\author{
Raymond P. Mauldin, Jason D. Weston, \\ and Cory J. Broehm
}

The magnetic susceptibility (MS) of a given sediment sample can be thought of as a measure of how easily that sample can be magnetized (Dearing 1999; Gose and Nickels 2001). At low magnetic field strengths, this measure is primarily related to the concentration and grain size of ferro- and ferromagnetic minerals in the sample. A number of processes can result in an increase in MS values in a sediment sample. Of these processes, those that are of concern here are related to an increase in the organic content or changes in the mineralogy of sediments in a given sample (see Collins et al. 1994; McClean and Kean 1993; Singer and Fine 1989). Sediments with higher organic content tend to have higher magnetic susceptibility values, probably as a result of the production of maghemite, an iron oxide, during organic decay (Reynolds and King 1995). Pedogenic processes, such as soil formation and weathering, can result in the concentration of organic material, as well as alterations in the mineralogy of a given zone. These processes can significantly impact susceptibility readings. Cultural processes, such as the concentration of ash, charcoal, and refuse, would also produce higher MS readings. A measure of the magnetic susceptibility of a sediment sample, then, may provide information on both the presence of formerly exposed surfaces, as well as a measure of the concentration of cultural activity upon those surfaces.

\section{Collection Procedures and Laboratory Methods}

A total of 27 samples, 17 from Block I and 10 from Block II, were collected from 41BX1412 for magnetic sediment susceptibility. The samples were collected at $5-\mathrm{cm}$ intervals along a given vertical stretch of a block profile. These samples were placed in plastic bags, and stored in the CAR laboratory until analysis.

Sediment samples from the two blocks were then air dried on a non-metal surface. After drying, the samples were then ground into a uniform grain size using a ceramic mortar and pestle. This was done to standardize particle size and make the material both easier to handle and pack into sample containers. After each sample was ground, the mortar and pestle was 
washed with tap water and wiped dry with a paper towel to avoid cross-sample contamination. The ground sample was then poured into a sample container consisting of a plastic cube with external dimensions of $2.54 \times 2.54 \times 1.94 \mathrm{~cm}$. The cubes have an average weight of 4.85 grams. The sediment filled cube was then weighed, and the weight of the sample calculated by subtracting the empty cube weight. This was done to correct for differences in mass. Assuming that sample volume and material is constant, larger samples should have higher susceptibility values simply as a function of greater mass.

The cube was then placed into a MS2B Dual Frequency Sensor that, in conjunction with a MS2 Magnetic Susceptibility Meter, provided a measure of the magnetic susceptibility of the sample (see Dearing 1999). For each cube, three distinct readings were taken using the SI (standard international) scale. These readings were then averaged to provide a single measure. The value, referred to as volume specific susceptibility and noted with the symbol K. (Kappa), is recorded on a scale of $10^{-5}$, though there are no units associated with the value. That is, the value is dimensionless (Dearing 1999).

In order to correct for differences in sample weight, and provide units to the value $K$, the mass specific susceptibility value (X) was calculated using the formula

$$
X=\left(K_{o} / p\right)
$$

where $\mathrm{p}$ is the sample bulk density expressed in $\mathrm{kg} \mathrm{m}^{-3}$. The bulk density is determined by dividing the sample mass by volume. However, as all samples were measured in identical cubes, and all cubes were full, the sample volume is assumed to be constant. Only the mass of the sample varied. Mass specific susceptibility can be determined by

$$
\mathrm{X}=\mathrm{K} * \text { calibrated mass/ sample mass }
$$

where sample mass is determined by subtracting the cube weight from the total sample weight (Dearing 1999). Calibrated mass is assumed to be 10 grams.
While the resulting values now have both a scale and associated units, the critical element for the current discussion is related to relative differences between X sample values within a given profile or site, rather than absolute differences. That is, the principal interest is in sudden and rapid changes in the mass specific susceptibility values along a profile. This change may signal either a buried surface and/or cultural activity at that location. Comparisons of absolute values between samples from different areas, especially when the parent material of the soils is different, are of limited utility given our current goals.

This can be seen in Table 6, which lists a variety of examples of mass specific susceptibility values for several different materials. In all cases, the analysis was performed following the procedures outlined previously. Note that the values differ widely, from a low of -1.47 for tap water, to a high of 97.62 for sediments collected from a burned rock midden. Samples 5 and 6 are on two different clays from the same general setting, northcentral Lamar County in northeast Texas. The mass specific susceptibility is different for these samples, probably as a function of different frequencies of trace elements that, though small in absolute quantity, can dramatically impact the susceptibility values.

The potential impacts of cultural processes on susceptibility values can be seen by considering a data set collected from an archaeological site located in Brown County, 41BR473. Sediment susceptibility samples were collected from each level of over 50 shovel tests placed at this site, for a total of 279 samples. In all cases, the analytical procedures followed those outlined previously. Table 7 presents summary data on all 279 cases, along with susceptibility scores for those settings that had FCR or chipped stone present. If cultural inputs result in higher susceptibility values, then it should be the case that significantly higher susceptibility values will be present in levels that have cultural material.

An examination of Table 7 will demonstrate that this is indeed the case. Levels that have FCR present do have higher scores relative to those that lack FCR. 
Table 6. Magnetic sediment susceptibility for a variety of substances

\begin{tabular}{|c|c|c|c|c|c|c|c|}
\hline Sample Type & $\begin{array}{c}\text { Total } \\
\text { Wt. (gr.) } \\
\end{array}$ & $\begin{array}{l}\text { Sample } \\
\text { Wt. (gr.) }\end{array}$ & $\begin{array}{c}\text { Reading } \\
1(k) \\
\end{array}$ & $\begin{array}{c}\text { Reading } \\
2(k) \\
\end{array}$ & $\begin{array}{c}\text { Reading } \\
\mathbf{3}(k) \\
\end{array}$ & $\begin{array}{c}\text { Average } \\
K \\
\end{array}$ & $\begin{array}{c}\text { Corrected } \\
\text { Mass }(X) \\
\end{array}$ \\
\hline $\begin{array}{l}\text { 1) Sandy sediment with } \\
\text { organics }\end{array}$ & 13.7 & 8.85 & 27.9 & 28 & 28.1 & 28 & 31.64 \\
\hline $\begin{array}{l}\text { 2) Modern mesquite } \\
\text { charcoal and sediment }\end{array}$ & 9.4 & 4.55 & 10.7 & 10.8 & 10.7 & 10.73 & 23.59 \\
\hline 3) Modern oak wood ash & 7.5 & 2.65 & 16.1 & 16.2 & 16.2 & 16.17 & 61.01 \\
\hline $\begin{array}{l}\text { 4) Sediment from burned } \\
\text { rock midden }\end{array}$ & 11.3 & 6.45 & 62.9 & 63 & 63 & 62.97 & 97.62 \\
\hline $\begin{array}{l}\text { 5) Gray clay - no human } \\
\text { occupation }\end{array}$ & 12.6 & 7.75 & 10.4 & 10.3 & 10.4 & 10.37 & 13.38 \\
\hline $\begin{array}{l}\text { 6) Red clay - no human } \\
\text { occupation }\end{array}$ & 10.8 & 5.95 & 11.9 & 12 & 12 & 11.97 & 20.11 \\
\hline 7) Sandstone & 14.7 & 9.85 & 6.9 & 7 & 7.1 & 7 & 7.11 \\
\hline 8) Limestone & 12.7 & 7.85 & -0.5 & -0.5 & -0.5 & -0.5 & -0.64 \\
\hline 9) Tap water & 10.5 & 5.65 & -0.8 & -0.8 & -0.9 & -0.83 & -1.47 \\
\hline
\end{tabular}

Table 7. Presence/absence of cultural material and mass specific sediment susceptibility scores for shovel tests at 41BR473

\begin{tabular}{|c|c|c|c|c|c|}
\hline \multirow{2}{*}{$\begin{array}{c}\text { Number of } \\
\text { Samples }\end{array}$} & \multirow{2}{*}{ All Cases } & \multicolumn{2}{|c|}{ FCR } & \multicolumn{2}{c|}{ Chipped Stone } \\
\cline { 2 - 6 } & 279 & 84 & 195 & 38 & 241 \\
\hline Mean Value & 48.3 & 56.9 & 44.6 & 55.2 & 47.2 \\
\hline $\begin{array}{c}\text { Standard } \\
\text { Deviation }\end{array}$ & 17.2 & 17.7 & 15.6 & 16.1 & 17.1 \\
\hline
\end{tabular}

Similarly, those levels that have chipped stone present have a higher average mass specific susceptibility score relative to those that lack chipped stone. As the distribution is approximately normal, a t-test was used to test the overall significance of these differences. In both the FCR and chipped stone comparisons the test confirms that those levels with cultural material have significantly higher scores than those without cultural material (FCR t-statistic $=5.804, \mathrm{df}=277, \mathrm{p}<.001$ chipped stone t-statistic $=2.674, \mathrm{df}=277, \mathrm{p}=.008$ ) Our preliminary investigations, then, coupled with the previous applications, clearly suggest that an analysis of the magnetic susceptibility of sediment can provide additional information on both the presence of buried surfaces, as well as the impact of cultural material on those surfaces. 


\section{Results}

Table 8 presents the results of the susceptibility analysis of the 27 samples at 41BX1412. Figures 16 and 17 present graphs of the mass specific values for each of the two blocks at the site. An examination of Figure 16 indicates a rapid decrease of values from the surface down to about $31.5 \mathrm{~cm}$, at which point the values stabilize around 51 . The high readings at the surface, followed by the rapid fall-off within the upper $35 \mathrm{~cm}$ and the consistency of the readings below that point suggests that only a single surface, reflected by the current ground surface, is present within Block I. While there are small deviations at around $42 \mathrm{~cm}$ and $65 \mathrm{~cm}$ below surface, these are of small magnitude. If these peaks in susceptibility correlate with higher artifact densities or changes in the assemblage composition, then they may be indicative of buried surfaces.

The pattern in Block II (Figure 17) is significantly different. Note both the increase in values as depth decreases from 0 to $22.5 \mathrm{~cm}$ below surface, as well as the dramatic spike in values at $27.5 \mathrm{~cm}$ below surface. While a variety of interpretations of these patterns can be provided, the pattern is consistent with a buried surface at 25 to $30 \mathrm{~cm}$ below surface, and a lack of organics associated with the modern-day surface.

Table 8. Sediment susceptibility data for 41BX1412

\begin{tabular}{|c|c|c|c|c|c|c|c|c|}
\hline $\begin{array}{c}\text { Block } \\
\#\end{array}$ & $\begin{array}{c}\text { Depth } \\
(\mathrm{cm} \mathrm{bs})\end{array}$ & $\begin{array}{c}\text { Total } \\
\text { Weight (gr.) }\end{array}$ & $\begin{array}{c}\text { Adjusted } \\
\text { Weight (gr.) }\end{array}$ & $\begin{array}{c}\text { Reading } \\
1(K) \\
\end{array}$ & $\begin{array}{c}\text { Reading } \\
2(\mathrm{~K}) \\
\end{array}$ & $\begin{array}{c}\text { Reading } \\
\mathbf{3}(\mathrm{K}) \\
\end{array}$ & $\begin{array}{c}\text { Average } \\
(\mathrm{K})\end{array}$ & $\begin{array}{l}\text { Corrected } \\
\text { Value }(X) \\
\end{array}$ \\
\hline 1 & 2 & 12 & 7.15 & 60.5 & 60.3 & 60.2 & 60.33 & 84.38 \\
\hline 1 & 6.5 & 12.3 & 7.45 & 53.6 & 53 & 53.2 & 53.27 & 71.5 \\
\hline 1 & 11.5 & 12.4 & 7.55 & 50.2 & 50.2 & 50.4 & 50.27 & 66.58 \\
\hline 1 & 16.5 & 12.8 & 7.95 & 46.3 & 46 & 46 & 46.1 & 57.99 \\
\hline 1 & 21.5 & 12.5 & 7.65 & 42.6 & 42.1 & 41.9 & 42.2 & 55.16 \\
\hline 1 & 26.5 & 12.5 & 7.65 & 39.9 & 39.4 & 39.6 & 39.63 & 51.81 \\
\hline 1 & 31.5 & 12.4 & 7.55 & 38 & 37.6 & 37.7 & 37.77 & 50.02 \\
\hline 1 & 36.5 & 12.5 & 7.65 & 38.3 & 38.2 & 38.3 & 38.27 & 50.02 \\
\hline 1 & 41.5 & 12.4 & 7.55 & 40.6 & 40.4 & 40.3 & 40.43 & 53.55 \\
\hline 1 & 46.5 & 12.4 & 7.55 & 38.6 & 38.8 & 38.3 & 38.57 & 51.08 \\
\hline 1 & 51.5 & 12.5 & 7.65 & 39.3 & 39.1 & 38.8 & 39.07 & 51.07 \\
\hline 1 & 56.5 & 12.6 & 7.75 & 38.9 & 39 & 39.1 & 39 & 50.32 \\
\hline 1 & 61.5 & 12.5 & 7.65 & 39.5 & 39.3 & 39.3 & 39.37 & 51.46 \\
\hline 1 & 66.5 & 12.4 & 7.55 & 40.6 & 40.5 & 40.5 & 40.53 & 53.69 \\
\hline 1 & 71.5 & 12.5 & 7.65 & 37.9 & 37.6 & 37.6 & 37.7 & 49.28 \\
\hline 1 & 76.5 & 12.4 & 7.55 & 38.6 & 38.6 & 38.4 & 38.53 & 51.04 \\
\hline 1 & 81.5 & 12.4 & 7.55 & 37.9 & 37.7 & 37.6 & 37.73 & 49.98 \\
\hline 2 & 2.5 & 12.2 & 7.35 & 57.9 & 57.8 & 57.7 & 57.8 & 78.64 \\
\hline 2 & 7.5 & 12.5 & 7.65 & 66.3 & 65.9 & 65.5 & 65.9 & 86.14 \\
\hline 2 & 12.5 & 12.4 & 7.55 & 66.5 & 66.7 & 66.4 & 66.53 & 88.12 \\
\hline 2 & 17.5 & 12.6 & 7.75 & 68.5 & 68.8 & 68.8 & 68.7 & 88.65 \\
\hline 2 & 22.5 & 12.6 & 7.75 & 68.1 & 68.4 & 68.2 & 68.23 & 88.04 \\
\hline 2 & 27.5 & 12.4 & 7.55 & 78.3 & 78 & 78.3 & 78.2 & 103.58 \\
\hline 2 & 32.5 & 12.5 & 7.65 & 65.6 & 65.7 & 65.8 & 65.7 & 85.88 \\
\hline 2 & 37.5 & 12 & 7.15 & 55.1 & 55.5 & 55.4 & 55.33 & 77.39 \\
\hline 2 & 42.5 & 12.5 & 7.65 & 57.7 & 57.4 & 57.4 & 57.5 & 75.16 \\
\hline 2 & 47.5 & 12.5 & 7.65 & 53.8 & 54.1 & 54.1 & 54 & 70.59 \\
\hline
\end{tabular}




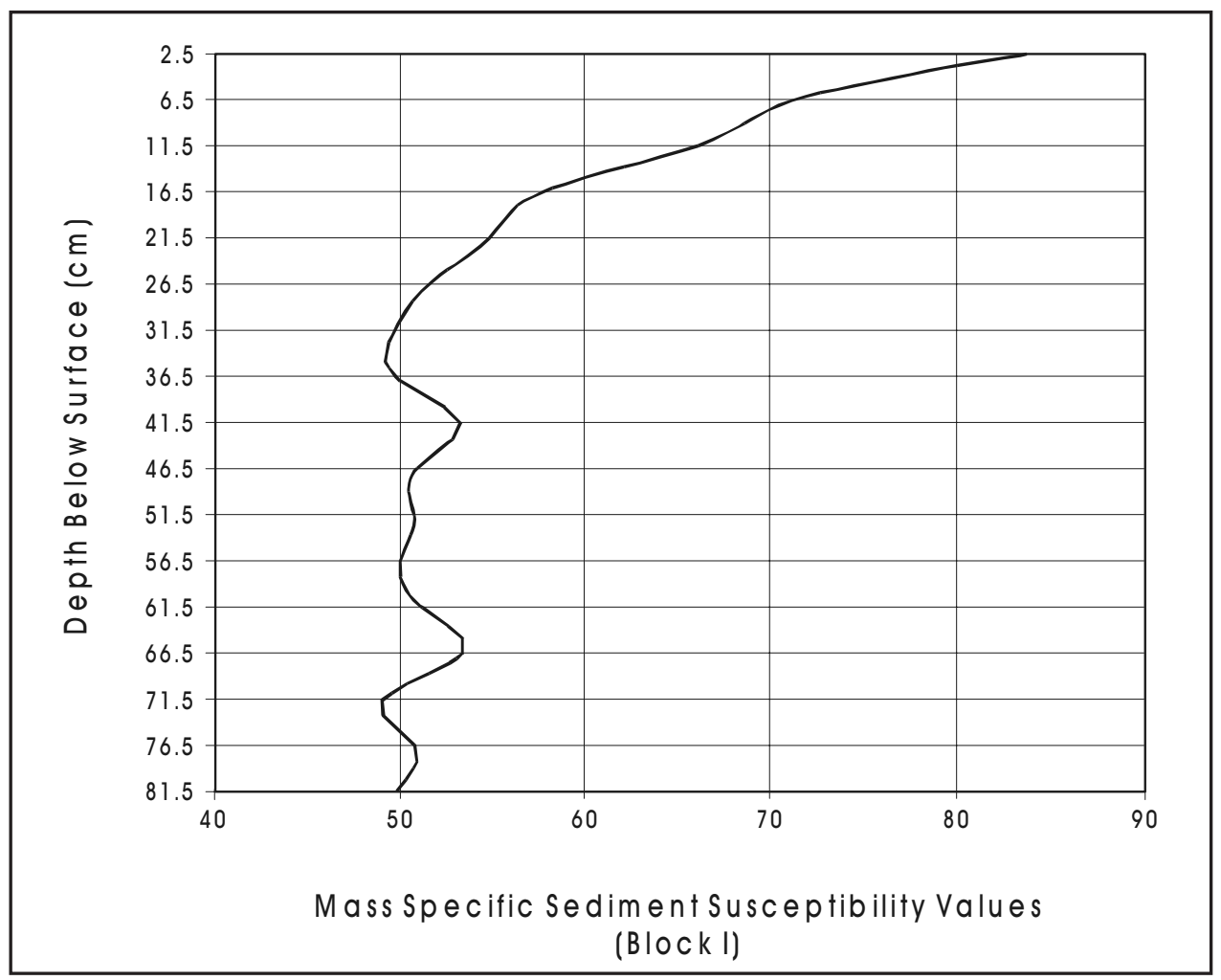

Figure 16. Mass specific sediment susceptibility values for samples from Block I.

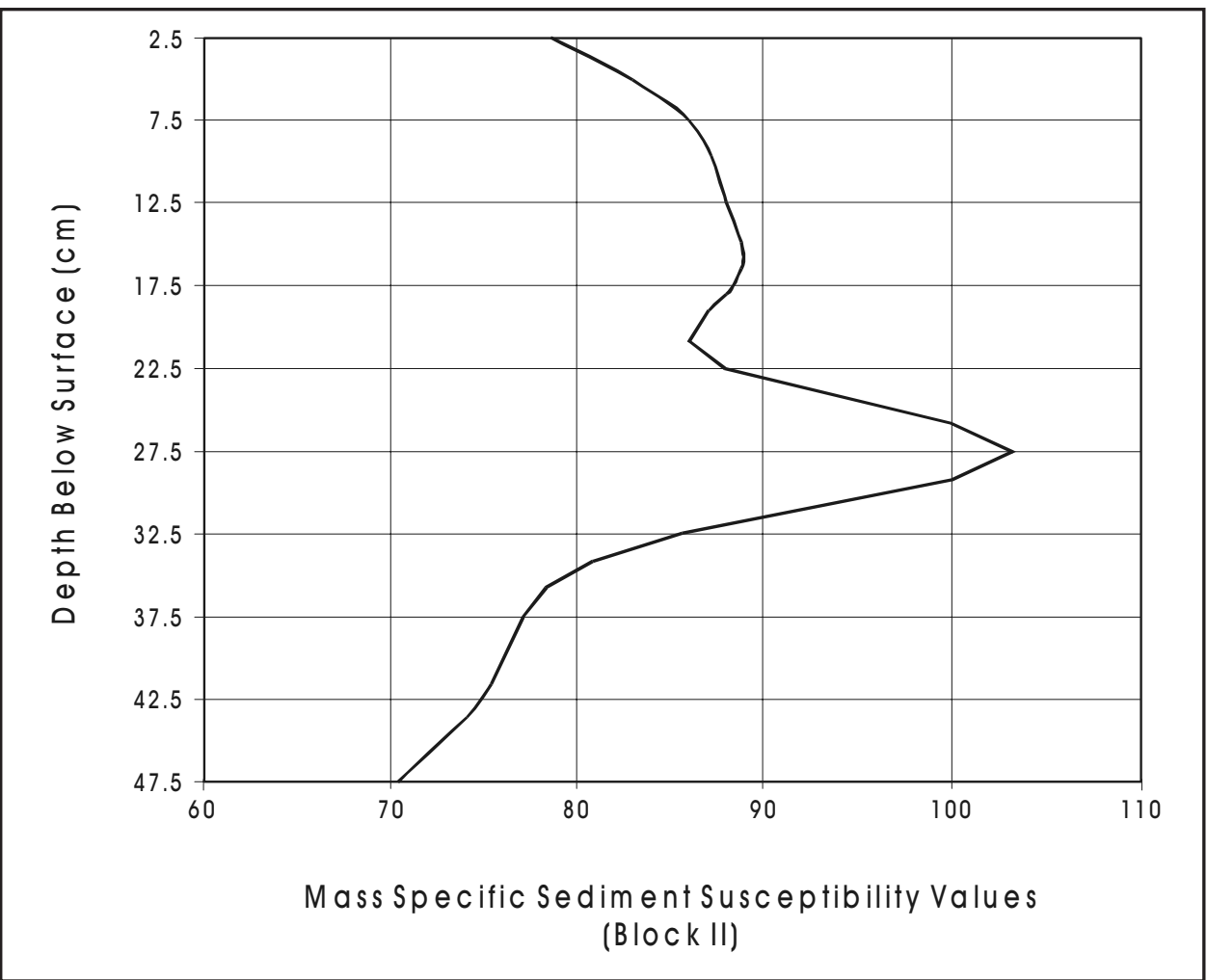

Figure 17. Mass specific sediment susceptibility values for samples from Block II. 


\section{Summary of Results}

Prior to data recovery efforts at $41 \mathrm{BX} 1412$, the results of testing phase analyses indicated that potentially two components, one Early Archaic and one possibly late Paleoindian, may be present on site (Tomka and Robinson 2000). Six Guadalupe adzes, a Uvalde dart point, numerous overshot flakes, and a heavily patinated perforator made from a recycled projectile point with Paleoindian morphological affinities, were recovered from the surface across the western half of the site during testing. Although during testing no diagnostics were recovered from the deeper levels of the site (i.e., below $50 \mathrm{~cm}$ ), the high proportion of patinated debitage below Level 6, the rather distinctive technological characteristics of the patinated debitage, and the patterning of debitage maximum dimension by depth, suggested that two components were present on site.

Data recovery efforts concentrated on identifying the two components and potentially recovering feature-associated subsistence data. The machine excavation of two perpendicular trenches through the east-central portion of the site revealed no identifiable features and/ or burned rock concentrations. The hand excavation of the blocks totaling $10 \mathrm{~m}^{2}$ and a total of $6.17 \mathrm{~m}^{3}$ of matrix yielded a number of temporally diagnostic artifacts including a Guadalupe adze recovered from Level 2 $(10-20 \mathrm{~cm}$ bs) of Unit II-5. In addition, two Pedernales dart point fragments were found in Level $3(20-30 \mathrm{~cm}$ bs) of units I-2 and II-1, respectively, and a third Pedernales fragment was found on the surface. The recovery of Pedernales points was unexpected given the lack of Middle Archaic and younger temporal diagnostics during testing and the recovery of older temporally diagnostic artifacts from the surface of the site during the previous phase of work. The fact that all seven of the Guadalupe adzes were recovered from higher in the site (six from the surface and one from Level 2) than two of the three Pedernales points suggests that some extreme disturbances may have affected the deposits of the site.

A similar conclusion can be reached by the relatively recent $\mathrm{C}-14$ date obtained on the sample of charcoal buried at $36 \mathrm{~cm}$ bs in Unit II-3. This recovery context is below the two buried Pedernales points yet its age (A.D. 1650-1950) is dramatically younger than the assumed date of the two Middle Archaic points (2500 400 B.C.; Hall et al. 1986).
Finally, the patterning in both the adjusted mean debitage counts (Figure 12), the distribution of burned rocks in the two blocks (Figure 15), and the dramatically different mass specific sediment susceptibility values between the two blocks (Figures 16 and 17), may be indicative of different depositional histories in the case of the two blocks.

Although a number of aspects of the site suggest the likelihood of disturbed deposits, at least five lines of evidence may also be indicative of the presence of a deeper depositional zone in at least Block I of the site. The factors that may be suggestive of this are: 1) the high percentage of patinated debitage in Level 6 and below; 2) the increased frequency of burned rocks in Levels 6 and 7;3) a slight increase in the mean maximum dimension of the debitage in Level 6; 4 ) a second peak in adjusted debitage counts in Level 6 ; and finally, 5) the presence of a peak in mass specific sediment susceptibility values somewhere around $65 \mathrm{~cm}$ bs.

The hand excavation of the ten units within the two blocks resulted in the identification of two soil zones. Zone 1 was thickest in Block I and thinned considerably towards the east across Block II. Zone 2 was also thickest in Block I and thinned considerably in Block II. The border between the two zones appeared to undulate in both blocks. Relatively loose limestone bedrock underlies Zone 2 in both blocks.

The variable thickness of the two zones across Blocks I and II suggests that the upper zone may represent fill that was added to the area to create a grade that slopes northeasterly towards Mud Creek. Alternatively, the upper zone in both blocks may represent an in situ matrix, the top portion of which may have been bladed off in Block II. Finally, a combination of both blading and filling may have taken place on selected portions of the site. The following section provides a reconstruction of the disturbances that may have led to the artifact distribution patterns outlined above.

During the construction of the original Bee Tree Drive, the relatively unstable clay matrix covering the bedrock was scraped down to solid bedrock. It is likely that this soil would have been spread on top of the area near the road to even the surface for picnic tables and parking lots. If the clay matrix contained an Early 
Archaic component (i.e., Guadalupe adzes and Uvalde points) these artifacts would have been redeposited on top of the previous surface. This process could explain the surface recovery of Early Archaic diagnostics off the western portion of the site during testing. It may also explain the recovery of Pedernales points below the only buried Guadalupe adze found during data recovery, if the original ground surface was occupied by Middle Archaic groups. The absence of a peak in mass specific sediment susceptibility values at, or near, the surface of Block II suggests the possibility that the original surface may have been removed through blading. On the other hand, the high peak that occurs in mass specific sediment susceptibility values around $27.5 \mathrm{~cm}$ bs may indicate either a second deeper occupation surface, or perhaps more likely, the possibility that the old surface has been buried under about $27 \mathrm{~cm}$ of fill.

\section{Conclusions and Recommendations}

The evidence for the presence of a late Paleoindian component at $41 \mathrm{BX} 1412$ rests on the reworked perforator with Paleoindian morphological characteristics and the presence of a number of overshot flakes and biface fragments with overshot flake scars. No evidence of an intact Paleoindian component was encountered during either testing or data recovery.

The evidence for an Early Archaic component is much stronger and consists of seven Guadalupe adzes, a Uvalde projectile point, and a number of tool forms (i.e., gravers and wood working tools) that have been interpreted as characteristic of Early Archaic assemblages (Collins et al. 1990; Johnson 1991). No intact Early Archaic component was identified at the site during testing and data recovery. However, the recovery of the diagnostic artifacts from the surface and in shallowly buried context overlying Middle Archaic projectile points suggests that matrix containing Early Archaic artifacts may have been excavated from under the original Bee Tree Drive and used as fill in portions of the ROW.

A Middle Archaic component, not previously revealed during testing, was identified as a result of data recovery work at the site. This component is represented by three Pedernales dart points, two of which were recovered in buried contexts. Whether the original Bee Tree Drive pre-construction ground surface represented a Middle Archaic occupation surface cannot be established at the present time. The reversed stratigraphy indicated by the temporally diagnostic artifacts suggests that fill excavated from the ROW was subsequently spread over the area burying the Middle Archaic surface. No clearly identifiable Middle Archaic features and component could be located on site.

Finally, radiocarbon dating of a sample of charcoal buried $36 \mathrm{~cm}$ bs yielded a relatively young date suggesting that the associated activity is intrusive into the deposits that also contained Middle Archaic Pedernales points. A single ceramic sherd of unknown origin and affiliation may belong with a possible Late Prehistoric component, but it is unclear whether the sherd is from a prehistoric or historic vessel.

Overall, data recovery work at 41BX1412 investigated a total of $128.5 \mathrm{~m}^{2}$ or approximately 8.5 percent of the site. While clear indications of Early and Middle Archaic components do exist at the site, no intact deposits of this age have been identified. The evidence for earlier (Paleoindian) and later components (possibly Late Prehistoric, Protohistoric) is inconclusive.

Given the complex depositional history and clearly disturbed nature of the Early Archaic deposits from 41BX1412, in addition to the lack of features and clearly identifiable intact buried occupation surfaces, CAR recommended in an interim report submitted to the Texas Historical Commission (October 11, 2000) that 41BX1412 is not eligible for listing to the National Register of Historic Places or designation as a State Archeological Landmark, and that no additional archaeological work needed to be carried out at the site. The interim report was necessary to present immediate results of the data recovery and obtain an expeditious opinion on the eligibility status recommendation. THC members concurred with the recommendation and the road construction was allowed to proceed as originally planned (Appendix A). Subsequent monitoring of the excavation of the remainder of the ROW impacting the site did not reveal any features and/or undisturbed archaeological deposits. 


\section{References Cited}

Black, S. L.

1989 Central Texas Plateau Prairie. In From the Gulf to the Rio Grande: Human Adaptation in Central, South, and Lower Pecos, Texas, by T. R. Hester, S. L. Black, D. G. Steele, B. W. Olive, A. A. Fox, K. J. Reinhard, and L. C. Bement, pp. 17-38. Research Series No. 33. Arkansas Archeological Survey, Fayetteville.

Black, S. L., and A. J. McGraw

1985 The Panther Springs Creek Site: Culture Change and Continuity within the Upper Salado Creek Drainage, South Central Texas. Archaeological Survey Report, No. 100. Center for Archaeological Research, The University of Texas at San Antonio.

Blair, W. F.

1950 The Biotic Provinces of Texas. Texas Journal of Science 2(1):93-117.

Boldurian, A. T.

1990 Lithic Technology at the Mitchell Locality of Blackwater Draw: A Stratified Folsom Site in Eastern New Mexico. Plains Anthropologist 35(130):1-115.

Bomar, G. W.

1995 Texas Weather. Second Edition, University of Texas Press, Austin.

Brown, K. M.

1985 Three Caches of Guadalupe Tools from South Texas. Bulletin of the Texas Archeological Society 56:75-126.

Callahan, E.

1979 The Basics of Biface Knapping in the Eastern Fluted Point Tradition: A Manual for Flintknappers and Lithic Analysts. Archaeology of Eastern North America 7(1):1-180.

Collins, M. B.

1995 Forty Years of Archeology in Central Texas. Bulletin of the Texas Archeological Society 66:361-400.

1999 Clovis Blade Technology: A Comparative Study of the Keven Davis Cache, Texas. University of Texas Press, Austin.

Collins, M. B., B. Ellis, and C. Dodt-Ellis

1990 Excavations at the Camp Pearl Wheat Site (41KR243): An Early Archaic Campsite on Town Creek, Kerr County, Texas. Studies in Archeology 6. Texas Archeological Research Laboratory, The University of Texas at Austin.

Collins, M. B., W. A. Gose, and S. Shaw

1994 Preliminary Geomorphological Findings at Dust and Nearby Caves. Journal of Alabama Archaeology 40:35-56.

Dearing, J.

1999 Environmental Magnetic Susceptibility. Chi Publishing, Kenilworth, England. 
Fox, A. A.

1973 An Archeological Survey of the Northeast Preserve and J Street Park San Antonio, Texas. Texas Archeological Research Laboratory, University of Texas at Austin.

1977 An Archaeological Assessment of the San Antonio 201 Wastewater Project. Archaeological Survey Report, No. 41. Center for Archaeological Research, The University of Texas at San Antonio.

1998 Stoneware Potteries in the San Antonio Area. Presentation at "From the Land-19 ${ }^{\text {th }}$ Century Texas Stoneware Seminar." National Wildflower Research Center, Austin.

Gose, W. A., and D. L. Nickels

2001[1998] Archaeomagnetic and Magnetic Susceptibility Analyses. In Test Excavations at the Culebra Creek Site, 41BX126, Bexar County, Texas, by D. L. Nickels, C. B. Bousman, J. D. Leach, and D. A. Cargill, pp. 204-214. Archaeological Survey Report, No. 265, Center for Archaeological Research, The University of Texas at San Antonio; Archeology Studies Program, Report 3, Environmental Affairs Division, Texas Department of Transportation, Austin.

Hall, G. D., T. R. Hester, and S. L. Black

1986 The Prehistoric Sites at Choke Canyon Reservoir, Southern Texas: Results of Phase II Archaeological Investigations. Choke Canyon Series 10. Center for Archaeological Research, The University of Texas at San Antonio.

Hester, T. R.

1971 Archeological Investigations at the La Jita Site, Uvalde County, Texas. Bulletin of the Texas Archeological Society 42:51-148.

1979 Early Populations in Prehistoric Texas. Archaeology 32(6):26-33.

1989 Introduction. In From the Gulf Coast to the Rio Grande: Human Adaptation in Central, South, and Lower Pecos Texas, by T. R. Hester, S. L. Black, B. W. Olive, A. A. Fox, K. Reinhart, and L. C. Bement, pp. 39-62. Research Series No. 33. Arkansas Archeological Survey, Fayetteville.

1995 The Prehistory of South Texas. Bulletin of the Texas Archeological Society 66:427-460.

Hester, T. R., and H. Kohnitz

1975 Chronological Placement of "Guadalupe" Tools. La Tierra 2(2):22-25.

Howard, C. D.

1990 The Clovis Point: Characteristics and Type Description. Plains Anthropologist 35(129):255-262.

Johnson, L., Jr.

1986 A Plague of Phases: Recent Sociocultural Taxonomy in Texas Archeology. Bulletin of the Texas Archeological Society 57:1-26.

1991 Early Archaic Life at the Sleeper Archaeological Site, 41BC65, of the Texas Hill Country, Blanco County, Texas. Publications in Archaeology, Report No. 39. Texas State Department of Highways and Public Transportation, Austin.

Johnson, L., Jr., and G. T. Goode

1994 A New Try at Dating and Characterizing Holocene Climates, as well as Archeological Periods, on the Eastern Edwards Plateau. Bulletin of the Texas Archeological Society 65:1-51. 
Katz, P. R.

1987 Archaeological Mitigation at 41BX300, Salado Creek Watershed, South-Central Texas. Archaeological Survey Report, No. 130. Center for Archaeological Research, The University of Texas at San Antonio.

Kibler, K. W., K. E. Stork, and L. W. Klement

1998 Archeological Survey at Camp Stanley Storage Activity, Bexar County, Texas. Reports of Investigations, No. 108. Prewitt and Associates, Inc., Austin.

McClean, R. G., and W. F. Kean

1993 Contributions of Wood Ash Magnetism to Archeomagnetic Properties of Fire Pits and Hearths. Earth and Planetary Science Letters 119:387-394.

Miller, G. L., and C. Sullivan

1984 Machine-made Glass Containers and the End of Production for Mouth-Blown Bottles. Historical Archaeology 18(2):81-96.

Potter, D. R., S. L. Black, and K. Jolly

1995 Archeology Along the Wurzbach Parkway, Module I Introduction: Conceptual Framework, and Contexts of Archeological Investigations in Bexar County, South-Central Texas. Studies in Archeology 17. Texas Archeological Research Laboratory, The University of Texas at Austin.

Prewitt, E. R.

1981 Cultural Chronology in Central Texas. Bulletin of the Texas Archeological Society 52:65-89.

1983 From Circleville to Toyah: Comments on Central Texas Chronology. Bulletin of the Texas Archeological Society 54:201-238.

Reynolds, R. L., and J. W. King

1995 Magnetic Records of Climate Change. U.S. National Report to I.U.G.G., 1991-1994. American Geophysical Union.

$<$ http://www.agu.ong/revgeophys/reyno100/reyno100.html $>$ Accessed April 2001.

Riskind, D. H., and D. D. Diamond

1986 Plant Communities of the Edwards Plateau of Texas: An Overview Emphasizing the Balcones Escarpment Zone Between San Antonio and Austin with Special Attention to Landscape Contrasts and Natural Diversity. In The Balcones Escarpment: Geology, Hydrology, Ecology and Central Texas, edited by P. L. Abbott and C. M. Woodruff, pp. 21-32. Comment Reproduction Service, Santa Fe Springs.

Scott, A. M., K. W. Kibler, M. D. Freeman, and S. P. Austin

1998 Archeological Survey and Testing at Camp Stanley Activity, Bexar County, Texas. Reports of Investigations, No. 115. Prewitt and Associates, Inc., Austin.

Singer, M. J., and P. Fine

1989 Pedogenic Factors Affecting Magnetic Susceptibility of Northern California Soils. Soil Science of America Journal 53:1119-1127. 
Sorrow, W. M., H. J. Shafer, and R. E. Ross

1967 Excavations at Stillhouse Hollow Reservoir. Miscellaneous Papers No. 11. Texas Archeological Salvage Project, The University of Texas at Austin.

Taylor, F. B., R. B. Hailey, and D. L. Richmond

1962 Soil Survey of Bexar County, Texas. United States Department of Agriculture, Soil Conservation Service.

Tomka, S. A., and A. A. Fox

1999a Archaeological Investigations of Rainwater Catchment Basins along the South Wall of Mission San José, San Antonio, Texas. Archaeological Survey Report, No. 287. Center for Archaeological Research, The University of Texas at San Antonio.

1999b Mission San José Repointing and Underpinning Project, San Antonio, Texas. Archaeological Survey Report, No. 294. Center for Archaeological Research, The University of Texas at San Antonio.

Tomka, S. A., and Robinson, R. C.

2000 The McAllister Park Roadway System Extension Project, San Antonio, Texas. Archaeological Survey Report, No. 301. Center for Archaeological Research, The University of Texas at San Antonio.

Turner, S. E., and T. R. Hester

1993 A Field Guide to Stone Artifacts of Texas Indians. Second Edition. Texas Monthly Field Guide Series. Gulf Publishing Company, Houston.

Waters, M. R.

1992 Principles of Geoarchaeology, A North American Perspective. The University of Arizona Press, Tucson. 



\section{Appendix A \\ Texas Historical Commission Concurrence Letter}




\section{The University of Texas $\star$ San Antonio}

Center for Archaeological Research

TEXAS HISTORICAL COMMISSION

October 16,2000

Mark Denton

Texas Antiquities Committee

P.O. Box 12276

Austin, Texas $78711-2276$

Dear Mr. Denton:

Enclosed please find two copies of the Interim Report for data recovery at site 41BX1412, McAllister Park, Texas Antiquities Permit No. 2466. Copies of this report have also been forwarded to Steve Uncapher at San Antonio Parks \& Recreation.

If you have any questions or if additional copies of the final report are needed, please feel free to contact me.

Sincerely,

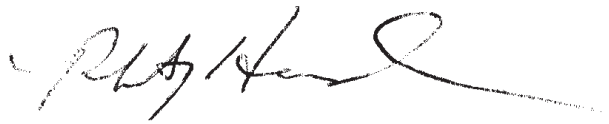

Robert J. Hard

Director

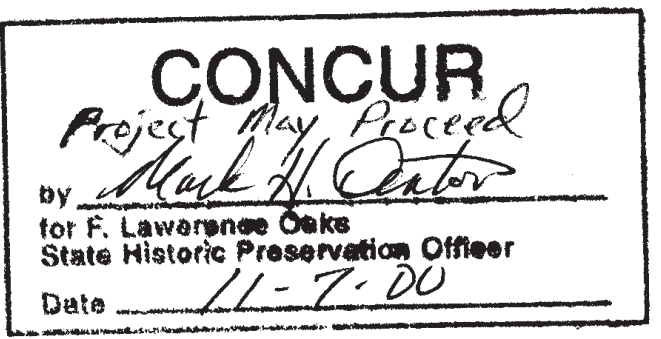

PECEYVE
CENTER FORAACHAEOLOGICAL
RESEAHCH
NOV 092000
UT SAN ANTONIO

6900 North Loop 1604 West • San Antonio, Texas 78249-0658 • (210) 458-4378 • (210) 458-4397 fax • car@Ionestar.utsa.edu 


\section{Appendix B \\ Beta Analytic Radiocarbon Date Form}




\section{CALIBRATION OF RADIOCARBON AGE TO CALENDAR YEARS}

(Variables: C 13/C 12=-25.1:lab. $\mathrm{mult}=1$ )

Laboratory number: Beta-152007

Conventional radiocarbon age: $200 \pm 60 \mathrm{BP}$

2 Sigm a calibrated results: Cal AD 1530 to 1560 (Cal BP 420 to 390 ) and (95\% probability) Cal AD 1630 to 1950 (Cal BP 320 to 0 )

Intercept data

Intercept of radiocarbon age with calibration curve:

1 Sigma calibrated results: (68\% probability)

\section{Cal AD 1670 (Cal BP 280)}

Cal AD 1650 to 1680 (Cal BP 300 to 260) and Cal AD 1730 to 1810 (Cal BP 220 to 140 ) and Cal AD 1930 to 1950 (Cal BP 20 to 0)

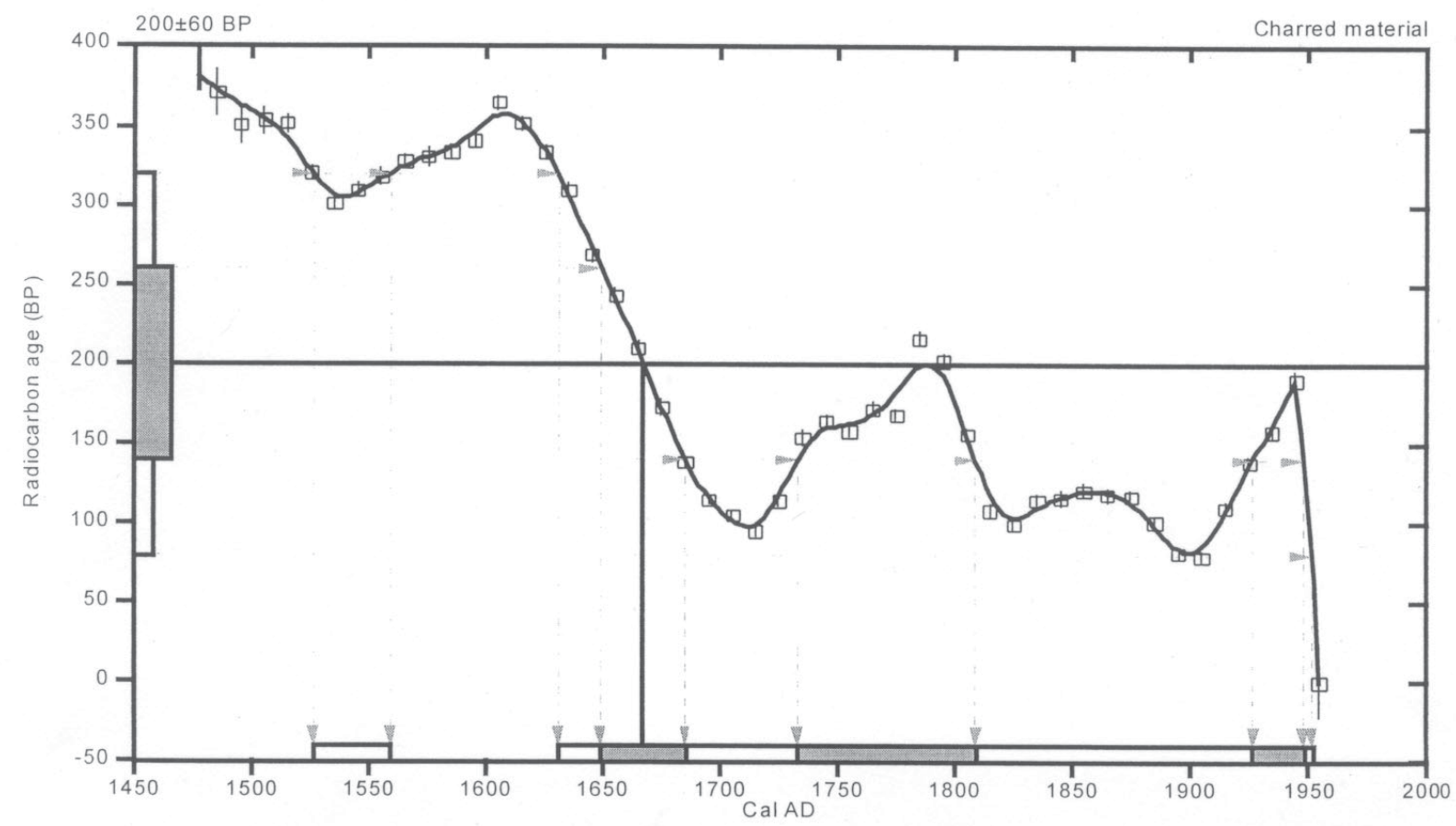

References:

Database used

Calibration Database Editorial Comment

Stuiver, M., van der Plicht, H., 1998, Radiocarbon 40(3), pxii-xiii

INTCAL98 Radiocarbon Age Calibration

Stuiver, M., et. al., 1998, Radiocarbon 40(3), p1041-1083

$M$ ath ematics

A Simplified Approach to Calibrating C14 Dates

Talma, A. S., Vogel, J. C., 1993, Radiocarbon 35(2), p317-322

\section{Beta Analytic Inc.}

4985 SW 74 Court. Miami, Florida 33155 USA Tel: (305) $6675167 \cdot$ Fax: (305) $6630964 \cdot$ E-Mail: beta@radiocarbon.com 


\section{Appendix C \\ Lithic Tools Recovered from 41BXI412}



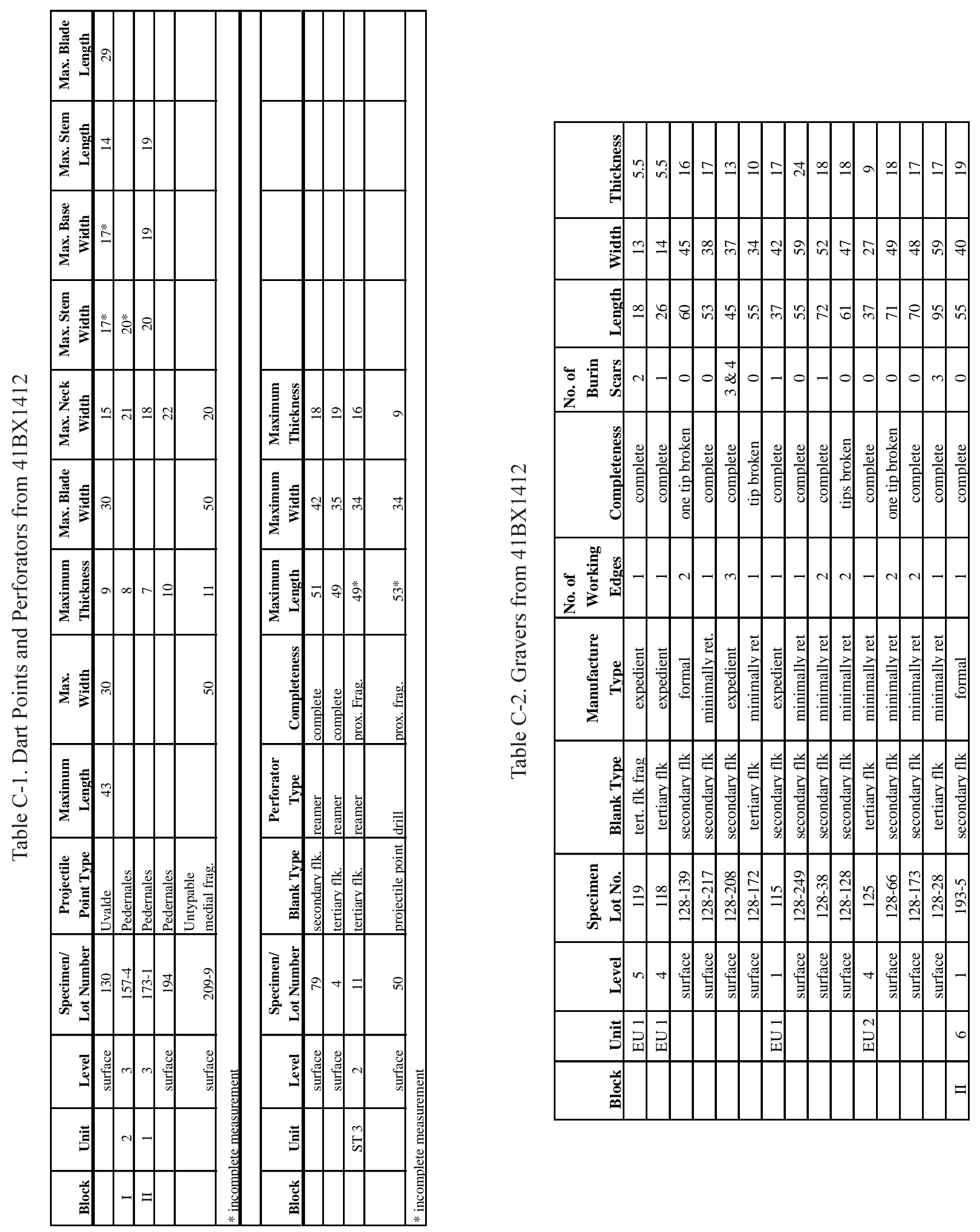
Table C-3. Adzes from 41BX1412

\begin{tabular}{|c|c|c|c|c|c|c|c|c|c|c|}
\hline Block & Unit & Level & $\begin{array}{c}\text { Specimen/ } \\
\text { Lot No. }\end{array}$ & $\begin{array}{c}\text { Manufacture } \\
\text { Type }\end{array}$ & $\begin{array}{c}\text { Adze } \\
\text { Type }\end{array}$ & $\begin{array}{c}\text { Edge } \\
\text { Angle }\end{array}$ & Completeness & Length & Width & Thickness \\
\hline & & surface & $128-129$ & formal & Guadalupe & 40 & distal end & $73 *$ & 36 & 27 \\
\hline & & surface & $128-168$ & formal & Guadalupe & 64 & complete & 98 & 34 & 24 \\
\hline & & surface & $128-104$ & formal & Guadalupe & 70 & distal frag & $40^{*}$ & 48 & 32 \\
\hline & & surface & $128-180$ & formal & Guadalupe & none & distal & $92 *$ & 38 & 37 \\
\hline & & surface & 128 & formal & Guadalupe & 70 & complete & 97 & 52 & 37 \\
\hline & & surface & $128-108$ & expedient & Expedient & 68 & distal & 75 & 55 & 33 \\
\hline II & 5 & 2 & $203-4$ & formal & Guadalupe & none & proximal & & 34 & 30 \\
\hline
\end{tabular}

* incomplete measurement

Table C-4. Scrapers and scraper planes from 41BX1412

\begin{tabular}{|c|c|c|c|c|c|c|c|c|c|}
\hline Block & Unit & Level & $\begin{array}{c}\text { Specimen/ } \\
\text { Lot No. }\end{array}$ & Blank Type & Uniface Type & Completeness & $\begin{array}{c}\text { Maximum } \\
\text { Length }\end{array}$ & $\begin{array}{c}\text { Maximum } \\
\text { Width }\end{array}$ & $\begin{array}{c}\text { Maximum } \\
\text { Thickness }\end{array}$ \\
\hline & & surf. & $128-163$ & secondary flk & comb. end/side scraper & complete & 63 & 49 & 17 \\
\hline & & surf. & $128-149$ & primary macro flk & scraper plane & complete & 124 & 97 & 40 \\
\hline & & surf. & $128-187$ & primary macro flk & scraper plane & complete & 109 & 58 & 49 \\
\hline I & 3 & 2 & $161-3$ & tertiary flk & expedient end scraper & complete & 23 & 39 & 10 \\
\hline I & 3 & 2 & $161-4$ & secondary flk & end scraper & complete & 50 & 67 & 18 \\
\hline
\end{tabular}

Table C-5. Choppers and wedges from 41BX1412

\begin{tabular}{|c|c|c|c|c|c|c|c|c|}
\hline Unit & Level & $\begin{array}{c}\text { Specimen } \\
\text { Lot No. }\end{array}$ & Complete & $\begin{array}{c}\text { Maximum } \\
\text { Length }\end{array}$ & $\begin{array}{c}\text { Maximum } \\
\text { Width }\end{array}$ & $\begin{array}{c}\text { Maximum } \\
\text { Thickness }\end{array}$ & $\begin{array}{c}\text { Use } \\
\text { Wear }\end{array}$ & Weight \\
\hline & surface & $128-7$ & Complete & 136 & 106 & 85 & present & 1072 \\
\hline & surface & $128-60$ & Complete & 122 & 86 & 76 & present & 731 \\
\hline & surface & $128-94$ & Complete & 158 & 102 & 59 & present & 1011 \\
\hline & surface & $128-126$ & Complete & 88 & 118 & 52 & present & 577 \\
\hline & surface & $128-u i 3$ & Complete & 85 & 82 & 44 & absent & 313 \\
\hline & surface & $128-214$ & Complete & 132 & 88 & 80 & present & 855 \\
\hline & surface & $128-310$ & Complete & 74 & 120 & 56 & present & 444 \\
\hline & surface & $128-251$ & Complete & 92 & 78 & 52 & absent & 339 \\
\hline & surface & $128-14$ & Complete & 153 & 102 & 35 & present & 690 \\
\hline & surface & $128-88$ & Complete & 114 & 73 & 35 & absent & 316 \\
\hline & surface & $128-184$ & Complete & 71 & 59 & 33 & absent & 146 \\
\hline ST 12 & 1 & 60 & Complete & 109 & 87 & 54 & minimal & 448 \\
\hline
\end{tabular}


Table C-6. Miscellaneous bifaces from 41BX1412

\begin{tabular}{|c|c|c|c|c|c|c|c|c|c|c|}
\hline Block & Unit & Level & $\begin{array}{l}\text { Specimen } \\
\text { Lot No. }\end{array}$ & Complete & $\begin{array}{c}\text { Reduction } \\
\text { Stage }\end{array}$ & $\begin{array}{l}\text { Break } \\
\text { Cause }\end{array}$ & $\begin{array}{c}\text { Maximum } \\
\text { Length }\end{array}$ & $\begin{array}{c}\text { Maximum } \\
\text { Width }\end{array}$ & $\begin{array}{l}\text { Maximum } \\
\text { Thickness }\end{array}$ & $\begin{array}{r}\text { Blank } \\
\text { Type } \\
\end{array}$ \\
\hline & & surface & 128-33 & Complete & middle & none & 117 & 45 & 21 & indet \\
\hline & & surface & 128-34 & Complete & early & none & 86 & 36 & 27 & pebble \\
\hline & & surface & $128-35$ & Complete & early-mid & none & 90 & 63 & 28 & flake \\
\hline & & surface & $128-18$ & proximal & early & manuf & 101 & 45 & 21 & indet \\
\hline & & surface & $128-20$ & Complete & early & none & 70 & 53 & 26 & pebble \\
\hline & & surface & $128-25$ & edge & middle & manuf & 40 & 38 & 15 & indet \\
\hline & & surface & 128-39 & Complete & early & none & 74 & 62 & 33 & pebble \\
\hline & & surface & 128-19 & edge & early & manuf & 34 & & 16 & indet \\
\hline & & surface & $128-58$ & Complete & early & none & 110 & 79 & 33 & pebble \\
\hline & & surface & $128-64$ & proximal & early & manuf & 69 & 53 & 27 & pebble \\
\hline & & surface & $128-65$ & distal & early & manuf & 63 & 54 & 17 & flake \\
\hline & & surface & $128-76$ & edge & early & manuf & 53 & 44 & 21 & indet \\
\hline & & surface & $128-80$ & Complete & early & none & 114 & 51 & 29 & indet \\
\hline & & surface & $128-82$ & medial & middle & manuf & 59 & 51 & 19 & indet \\
\hline & & surface & $128-83$ & proximal & early & manuf & 68 & 65 & 16 & flake \\
\hline & & surface & $128-84$ & proximal & early & manuf & 47 & 39 & 16 & flake \\
\hline & & surface & $128-86$ & proximal & early & manuf & 50 & 52 & 14 & flake \\
\hline & & surface & $128-87$ & proximal & medial & manuf & 43 & 75 & 13 & indet \\
\hline & & surface & 128-95 & proximal & early & manuf & 78 & 69 & 19 & indet \\
\hline & & surface & 128-102 & Complete & early & none & 110 & 55 & 19 & indet \\
\hline & & surface & $128-111$ & proximal & early & manuf & 53 & 71 & 20 & indet \\
\hline & & surface & 128-115 & proximal & early & manuf & 54 & 63 & 16 & flake \\
\hline & & surface & $128-118$ & wedge & early & manuf & 25 & 57 & 12 & flake \\
\hline & & surface & $128-136$ & Complete & early & none & 69 & 68 & 34 & pebble \\
\hline & & surface & $128-138$ & Complete & early-mid & none & 142 & 61 & 29 & indet \\
\hline & & surface & $128-167$ & edge & middle & indet & 44 & 27 & 14 & indet \\
\hline & & surface & $128-176$ & medial & early & manuf & 52 & 54 & 16 & flake \\
\hline & & surface & $128-179$ & proximal & middle & manuf & 37 & 38 & 10 & indet \\
\hline & & surface & $128-182$ & proximal & early & manuf & 58 & 57 & 18 & indet \\
\hline & & surface & 128-ui 20 & Complete & middle & none & 74 & 36 & 14 & flake \\
\hline & & surface & 128-ui 10 & Complete & early & none & 100 & 69 & 30 & indet \\
\hline & & surface & 128-ui 8 & proximal & early & manuf & 60 & 50 & 18 & flake \\
\hline & & surface & 128-ui 20 & proximal & medial & manuf & 44 & 41 & 11 & indet \\
\hline & & surface & 128-ui 4 & Complete & early & none & 67 & 54 & 23 & indet \\
\hline & & surface & $128-183$ & Complete & early & none & 97 & 62 & 33 & indet \\
\hline & & surface & 128-184 & Complete & early & none & 71 & 59 & 33 & indet \\
\hline & & surface & $128-185$ & proximal & early & indet & 76 & 56 & 30 & pebble \\
\hline & & surface & 128-205 & distal & middle & manuf & 51 & 58 & 13 & indet \\
\hline & & surface & $128-216$ & distal & middle & manuf & 59 & 41 & 17 & indet \\
\hline & & surface & $128-204$ & proximal & early & manuf & 46 & 43 & 14 & flake \\
\hline & & surface & $128-306$ & Complete & middle & none & 87 & 53 & 27 & indet \\
\hline & & surface & $128-5$ & distal & early-mid & manuf & 52 & 35 & 19 & indet \\
\hline & & surface & $128-252$ & Complete & early & none & 113 & 72 & 37 & pebble \\
\hline & & surface & $128-207$ & Complete & middle & none & 74 & 34 & 17 & indet \\
\hline & & surface & $128-236$ & proximal & middle & indet & 40 & 50 & 11 & indet \\
\hline & & surface & $128-237$ & proximal & early & indet & 85 & 46 & 21 & indet \\
\hline & & surface & $128-307$ & Complete & early & none & 117 & 86 & 38 & pebble \\
\hline & & surface & $128-308$ & Complete & early & none & 136 & 114 & 45 & pebble \\
\hline
\end{tabular}


Table C-6. continued...

\begin{tabular}{|c|c|c|c|c|c|c|c|c|c|c|}
\hline Block & Unit & Level & $\begin{array}{c}\text { Specimen } \\
\text { Lot No. }\end{array}$ & Complete & $\begin{array}{c}\text { Reduction } \\
\text { Stage }\end{array}$ & $\begin{array}{l}\text { Break } \\
\text { Cause } \\
\end{array}$ & $\begin{array}{c}\text { Maximum } \\
\text { Length }\end{array}$ & $\begin{array}{c}\text { Maximum } \\
\text { Width } \\
\end{array}$ & $\begin{array}{l}\text { Maximum } \\
\text { Thickness }\end{array}$ & $\begin{array}{r}\text { Blank } \\
\text { Type } \\
\end{array}$ \\
\hline & & surface & $128-312$ & medial & mid-late & manuf & 30 & 62 & 13 & indet \\
\hline & & surface & $128-281$ & proximal & early & manuf & 58 & 57 & 18 & flake \\
\hline & & surface & 128-ui 10 & Complete & early & none & 102 & 68 & 31 & indet \\
\hline & & surface & 128-ui 21 & proximal & early-mid & manuf & 43 & 27 & 7 & flake \\
\hline & & surface & $128-124$ & Complete & early & none & 106 & 80 & 35 & flake \\
\hline & ST 16 & 5 & 89 & medial & middle & manuf & 38 & 43 & 12 & indet \\
\hline & ST 17 & 1 & 91 & Complete & early & none & 107 & 56 & 21 & flake \\
\hline & ST 15 & surface & 78 & distal & early & manuf & 54 & 49 & 18 & indet \\
\hline & Unit 2 & 3 & 124 & longitudinal & early & manuf & 52 & 35 & 16 & indet \\
\hline & Unit 2 & surface & 121 & distal & middle & manuf & 61 & 50 & 12 & indet \\
\hline & Unit 1 & 2 & 116 & medial & middle & manuf & 45 & 28 & 12 & indet \\
\hline & Unit 1 & 1 & 115 & biface edge & middle & indet & & & 7 & indet \\
\hline & ST 17 & 2 & 92 & distal & early & indet & 33 & 20 & 15 & indet \\
\hline II & 2 & 4 & $179-5$ & distal & indet. & indet & 13 & 10 & 5 & indet \\
\hline $\mathrm{I}$ & 3 & 3 & $162-6$ & biface edge & indet. & post-depositional & & & 5 & indet \\
\hline II & 4 & 5 & $190-3$ & biface edge & indet. & indet & & & 7 & indet \\
\hline & & surface & $245-1$ & medial & early & manuf & 35 & 40 & 15 & indet \\
\hline II & 3 & 3 & $183-3$ & distal & early & indet & 12 & 16 & 4 & indet \\
\hline II & 1 & 1 & $171-4$ & medial & early & manuf & 40 & 50 & 23 & indet \\
\hline II & 6 & 1 & $193-6$ & distal & middle & post-depositional & 69 & 52 & 13 & indet \\
\hline N-S Trench & & $20-35$ & $196-6$ & distal & middle & manuf & 52 & 60 & 22 & indet \\
\hline II & 1 & 1 & $171-5$ & distal & early & indet & 40 & 35 & 18 & indet \\
\hline & & surface & $245-2$ & biface edge & middle & indet & & & 11 & indet \\
\hline $\mathrm{I}$ & 1 & 2 & $151-4$ & proximal & early & manuf & 23 & 51 & 17 & flake \\
\hline $\mathrm{I}$ & 2 & 2 & $156-4$ & biface edge & middle & manuf & & & 15 & indet \\
\hline $\mathrm{I}$ & 2 & 3 & $157-3$ & Complete & early & none & 86 & 53 & 26 & pebble \\
\hline $\mathrm{I}$ & 4 & 2 & $166-4$ & proximal & early & manuf & 98 & 76 & 20 & indet \\
\hline N-S Trench & & $20-35$ & 196-8 & proximal & early & manuf & 86 & 62 & 25 & indet \\
\hline I & 3 & surface & 195 & proximal & early & manuf & 37 & 33 & 7 & flake \\
\hline II & 4 & 1 & $186-3$ & medial & finished & use & 15 & 22 & 6 & indet \\
\hline $\mathrm{I}$ & 4 & 2 & $166-7$ & proximal & early & manuf & 63 & 56 & 24 & pebble \\
\hline E-W Trench & & surface & $209-8$ & Complete & early & none & 77 & 67 & 41 & pebble \\
\hline $\mathrm{I}$ & 3 & 5 & $164-3$ & medial & middle & manuf & 55 & 27 & 6 & indet \\
\hline $\mathrm{I}$ & 4 & 3 & $167-3$ & medial & finished & use & & & 4 & indet \\
\hline $\mathrm{I}$ & 4 & 7 & 201-3 & distal & finished & use & & & 5 & indet \\
\hline $\mathrm{I}$ & 2 & 6 & $199-3$ & distal & finished & use & & & 5 & indet \\
\hline
\end{tabular}


Table C-7. Miscellaneous unifaces from 41BX1412

\begin{tabular}{|c|c|c|c|c|c|c|c|c|c|}
\hline Block & Unit & Level & $\begin{array}{c}\text { Specimen } \\
\text { Lot No. }\end{array}$ & Blank Type & Uniface Type & Completeness & Length & Width & Thickness \\
\hline & ST 20 & 2 & 110 & secondary flk & indeterminate frag. & proximal & & & 11.5 \\
\hline & EU 2 & 6 & 127 & primary flk & indet. distal frag. & distal & & 37.5 & 21 \\
\hline & EU 2 & 4 & 9 & secondary flk & indet. edge frag. & edge frag. & & & 6 \\
\hline & & surf. & $128-40$ & secondary flk & minimally ret & complete & 66 & 49 & 16 \\
\hline $\mathrm{I}$ & 2 & 2 & $156-3$ & secondary flk & indet., prox., frag. & proximal & & 43 & 17 \\
\hline E-W Trench & & surf. & $209-4$ & primary flk & indet., prox., frag. & proximal & & 68 & 17 \\
\hline $\mathrm{I}$ & 1 & 1 & $150-4$ & secondary flk & indeterminate uniface & complete & 72 & 54 & 16 \\
\hline II & 5 & 1 & $192-6$ & tertiary flk & indet., prox., frag. & proximal & & & 23 \\
\hline $\mathrm{I}$ & 3 & 3 & $162-5$ & secondary flk & ind., distal fragment & distal & & & 13 \\
\hline I & 3 & 3 & $162-6$ & tertiary flk & ind., edge fragment & edge frag. & & & 2 \\
\hline II & 5 & 2 & 203-3 & tertiary flk & end scraper preform & complete & 55 & 50 & 14 \\
\hline Trench 1 & & $20-35$ & $196-7$ & tertiary flk & reworked end scraper & complete & 51 & 57 & 14 \\
\hline
\end{tabular}


Table C-8. Cores from 41BX1412

\begin{tabular}{|c|c|c|c|c|c|c|c|c|c|}
\hline Block & Unit & Level & $\begin{array}{c}\text { Specimen/ } \\
\text { Lot No. }\end{array}$ & Complete & $\begin{array}{c}\text { No. of Flk. } \\
\text { Scars } \\
\end{array}$ & $\begin{array}{l}\text { Core } \\
\text { Type }\end{array}$ & $\begin{array}{c}\text { Maximum } \\
\text { Length }\end{array}$ & $\begin{array}{c}\text { Maximum } \\
\text { Width }\end{array}$ & $\begin{array}{c}\text { Maximum } \\
\text { Thickness } \\
\end{array}$ \\
\hline & & surface & $128-36$ & Complete & 12 & multi-direct & 87 & 79 & 39 \\
\hline & & surface & $128-37$ & Complete & 9 & unidirect & 82 & 77 & 37 \\
\hline & & surface & $128-8$ & Complete & 9 & multi-direct & 81 & 67 & 63 \\
\hline & & surface & $128-22$ & Complete & 3 & multi-direct & 61 & 50 & 34 \\
\hline & & surface & $128-41$ & Complete & 8 & unidirect & 70 & 68 & 53 \\
\hline & & surface & $128-43$ & Complete & 1 & unidirect & 84 & 72 & 34 \\
\hline & & surface & $128-62$ & Complete & 6 & unidirect & 112 & 104 & 62 \\
\hline & & surface & $128-75$ & Complete & 2 & multi-direct & 101 & 71 & 52 \\
\hline & & surface & $128-90$ & Complete & 11 & unidirect & 75 & 60 & 42 \\
\hline & & surface & $128-100$ & Complete & 8 & unidirect & 110 & 82 & 70 \\
\hline & & surface & $128-110$ & Complete & 6 & unidirect & 73 & 58 & 38 \\
\hline & & surface & 128-114 & Complete & 23 & unidirect & 82 & 48 & 45 \\
\hline & & surface & $128-127$ & Complete & 4 & bidirect & 120 & 64 & 55 \\
\hline & & surface & $128-137$ & Fragmentary & 11 & multi-direct & 72 & 72 & 48 \\
\hline & & surface & $128-143$ & Complete & 7 & bidirect & 59 & 54 & 47 \\
\hline & & surface & $128-156$ & Complete & 5 & multi-direct & 66 & 50 & 49 \\
\hline & & surface & $128-170$ & Complete & 12 & multi-direct & 72 & 55 & 38 \\
\hline & & surface & $128-177$ & Complete & 8 & unidirect & 78 & 68 & 35 \\
\hline & & surface & 128-ui 6 & Complete & 4 & unidirect & 79 & 69 & 43 \\
\hline & & surface & 128-ui 5 & Complete & 1 & unidirect & 141 & 123 & 50 \\
\hline & & surface & 128-188 & Complete & 14 & unidirect & 74 & 51 & 30 \\
\hline & & surface & $128-190$ & Complete & 9 & unidirect & 85 & 60 & 43 \\
\hline & & surface & 128-192 & Complete & 4 & unidirect & 87 & 61 & 32 \\
\hline & & surface & 128-ui 13 & Complete & 9 & multi-direct & 77 & 58 & 41 \\
\hline & & surface & 128-191 & Complete & 5 & bidirect & 112 & 87 & 27 \\
\hline & & surface & $128-231$ & Complete & 6 & bidirect & 98 & 68 & 61 \\
\hline & & surface & 128-239 & Complete & 3 & unidirect & 79 & 69 & 46 \\
\hline & & surface & $128-309$ & Complete & 5 & unidirect & 86 & 49 & 44 \\
\hline & & surface & $128-213$ & Complete & 5 & unidirect & 97 & 64 & 45 \\
\hline & & surface & $128-210$ & Complete & 2 & unidirect & 82 & 61 & 44 \\
\hline & & surface & $128-212$ & Complete & 7 & bidirect & 79 & 74 & 64 \\
\hline & & surface & $128-220$ & Complete & 8 & multi-direct & 91 & 76 & 51 \\
\hline & & surface & $128-223$ & Complete & 6 & bidirect & 137 & 106 & 86 \\
\hline & & surface & $128-311$ & Complete & 5 & unidirect & 89 & 72 & 22 \\
\hline & & surface & $128-211$ & Complete & 2 & multi-direct & 73 & 64 & 51 \\
\hline & & surface & $128-239$ & Complete & 3 & unidirect & 81 & 62 & 43 \\
\hline & & surface & $128-233$ & Complete & 3 & unidirect & 73 & 67 & 39 \\
\hline & & surface & $128-230$ & Complete & 7 & unidirect & 130 & 111 & 63 \\
\hline & ST 10 & 2 & 49 & Complete & 3 & unidirect & 35 & 31 & 22 \\
\hline II & 6 & 1 & 193-3 & Complete & 12 & multi-direct & 80 & 61 & 52 \\
\hline N-S Trench & & $20-35$ & 196-1 & Complete & 6 & unidirect & 61 & 103 & 74 \\
\hline II & 3 & 1 & $181-3$ & Complete & 8 & bidirect & 55 & 82 & 58 \\
\hline E-W Trench & & surface & $209-7$ & Complete & 3 & unidirect & 75 & 58 & 51 \\
\hline II & 2 & 1 & $176-1$ & Complete & 3 & unidirect & 38 & 66 & 45 \\
\hline E-W Trench & & surface & 209-5 & Complete & 15 & multi-direct & 27 & 62 & 53 \\
\hline N-S Trench & & $20-35$ & $196-3$ & Complete & 4 & bidirect & 74 & 62 & 41 \\
\hline II & 6 & 1 & $193-4$ & Fragmentary & 5 & bidirect & 21 & 38 & 36 \\
\hline
\end{tabular}

